\title{
West Scandinavian Ditransitives as a family of constructions: With a special attention to the Norwegian 'V-REFL-NP' Construction
}

\author{
JÓHANNA BARĐDAL, KRISTIAN EMIL KRISTOFFERSEN AND ANDREAS SVEEN
}

Abstract

In this article we show that the semantic characterization of the English Ditransitive Construction, primarily based on the concept of transfer and generally assumed in the international literature within Construction Grammar, is insufficient for the remaining branches of Germanic, in particular for the West-Scandinavian languages, both modern and ancient. On the basis of our findings from West-Scandinavian we suggest eight semantic subconstructions of the Ditransitive Construction, which in turn can be divided into 17 different narrowly-circumscribed semantic verb classes. We depict the semantics of the construction on a semantic map, and lay out the internal structure of the construction on a lexicality-schematicity hierarchy where both higher-level generalizations and lower-level idiosyncrasies are captured. Finally, we investigate a specific subconstruction of the Ditransitive in Norwegian, the V-REFL-NP Construction, which shows certain idiosyncratic properties, not derivable from any general or specific syntactic rules of Norwegian, nor from the semantics of the individual parts. We conclude that a constructional analysis is needed to satisfactorily account for all the facts of the Ditransitive Construction in Norwegian and WestScandinavian. ${ }^{1}$

\section{Introduction}

Most construction-based work on the Ditransitive Construction has hitherto been based on English data, highlighting transfer as the main semantic component of the construction (Goldberg 1995; Croft 2003). In a recent article by Barðdal (2007), focusing on data from Icelandic with some comparison with Norwegian and Swedish dialects, it is shown that not only verbs denoting actual, intended, retained and metaphorical transfer instantiate the Ditransitive Construction, but also verbs of transfer along a path, verbs of possession, utilizing, enabling, hindrance, constraining and verbs denoting mental activities. The Icelandic analysis motivates an additional study on the semantic and lexical scope of the Ditransitive Construction in WestScandinavian, i.e., Icelandic, Faroese and Norwegian, and their predecessor, Old Norse, in order to reveal whether the semantic scope of the construction has expanded in Icelandic or contracted in English. Also, the Icelandic (2007) analysis is confined to the prototypical Dat-Acc Ditransitive Construction, which means that further research into the four less prototypical subconstructions of the Ditransitive in West- 
Scandinavian, i.e., Dat-Dat, Dat-Gen, Acc-Dat, Acc-Gen, is in place.

We start the present discussion by summarizing and further refining the semantic typology developed by Barðdal (2007), suggesting the following eight higher-level semantic categories: ACTUAL TRANSFER, INTENTION, CREATION, MODE OF COMMUNICATION, ENABLING, RETAINING, MENTAL PROCESSES and POSSESSION. These can be depicted as adjacent categories in semantic space. An analysis of the predicates occurring in the Ditransitive Construction in Faroese and Norwegian confirms this typology; the same seventeen verb classes that instantiate the Ditransitive Construction in Icelandic, are also found in Faroese and Norwegian. A comparison with Old Norse, including the five different subconstructions of the Ditransitive Construction in that language stage, differentiated by different case frames, further sustains the validity of our semantic map.

We suggest, moreover, a lexicality-schematicity hierarchy for the Ditransitive Construction in West-Scandinavian, where higher-level categories are located at the top of the hierarchy and less general constructions at the lower levels, including both verb-class-specific and verb-specific constructions. We thus use lexicalityschematicity hierarchies to capture both higher-level generalizations and lower-level verb-specific idiosyncrasies. Lexicality-schematicity hierarchies are structured inventories of lexicon-grammar interactions, ideal for research within lexical typology which is one of the cornerstones of comparative constructional work.

One of the idiosyncratic properties of some of the subconstructions of the Ditransitive in the West-Scandinavian languages lies in the fact that the indirect object can only be reflexive. A further examination of one of these subconstructions, which we have here labeled $V$-REFL-NP Construction, reveals idiosyncrasies not derivable from any general or specific syntactic rules, nor from the semantics of the parts. This includes a higher degree of agentivity, or extra effort, on behalf of the subject referent, and a particularly enjoyable end result. Neither of these semantic properties can be derived from the semantics of the individual parts. We suggest a pragmaticallymotivated extension of the Ditransitive Construction, based on the fact that the instigator and the beneficiary of the event have the same reference, hence the reflexivity of the indirect object. As people are more likely to actively involve themselves in obtaining enjoyable objects/end results, rather than non-enjoyable objects/end results, a contextually-driven extension may have arisen through repeated use. Given that there seems to be a natural basis for this pragmatic extension, it is expected that this particular semantic effect with ditransitives may be found in more languages. Indeed, similar effects seem to occur in Ditransitive Constructions involving reflexives in at least Icelandic, English, French and Polish.

We start in Section 2 by presenting the main tenets of Construction Grammar, before we proceed, in Section 3, to a definition of our object of investigation, the Ditransitive Construction, and a delimitation of our study. Section 4 is devoted to a comparison of the verb classes found in the construction in the West-Scandinavian languages and the semantic generalizations that can be made. Section 5 contains a thorough description of the syntactic and semantic properties of the V-REFL-NP Construction in Norwegian. Section 6 summarizes our main findings and the content of this article.

\section{A constructional approach}

All versions of Construction Grammar share the basic tenet that linguistic units are 
form-meaning/form-function correspondences, termed constructions (see the overview in Croft and Cruse 2004: 257-290 and Goldberg 2006: 5-9). These linguistic units, the constructions, differ along several parameters, such as the following:

- General vs. specific semantics

- Predictable vs. idiosyncratic syntactic behavior

- Location at the syntax-lexicon continuum

- Location on the lexicality-schematicity hierarchy

Constructions may of course vary along more parameters than these, although these are the ones that are of most relevance for the discussion in the present article.

Beginning with the first bulleted point above, constructions vary as to how general or specific their semantics is (Tomasello 1998: 481-482; Croft and Cruse 2004: 253-254). That is, whether they are semantically general, with the semantics of the whole being derivable from the semantics of the parts, or whether they are semantically specific, with the semantics of the whole not being derivable from the semantics of the parts. The latter category, also referred to in the literature as semantically non-compositional, encompasses various kinds of idiomatic expressions and set phrases, ranging from partly idiomatic to completely idiomatic expressions (Nunberg et al. 1994, Fillmore et al. 1998).

Turning to the second bulleted point, constructions also vary as to whether their syntactic behavior accords with the general syntactic rules of the language or whether they show idiosyncratic syntactic behavior (Jackendoff 1997; Fillmore et al. 1998). The classical example involves the idiom kick the bucket which cannot occur in the passive construction in its non-literal meaning 'die' (cf. Gibbs 1995):

*The bucket was kicked by John.

Regarding the third bulleted point, all linguistic material can be accounted for on a syntax-lexicon continuum, shown in Table 1 from Croft and Cruse (2004: 255). On this approach, larger sentence-level constructions are viewed as differing from constructions at the word level or morpheme level, as being complex and schematic, while constructions at the word level are atomic and substantive and constructions at the morpheme level are bound and substantive. The basic attractiveness of this approach is that all linguistic units can be accounted for in a uniform way, namely as form-function/meaning correspondences, only differing as to the construction's level of complexity and substance.

The last bulleted point above relates to the schematicity vs. lexicality of constructions. For instance, syntactic and complex constructions can exist both as schematic constructions and as substantive or lexically-filled instances of more schematic constructions. An example would be the schematic The X-er, the Y-er construction and its substantive, lexically-filled variant, The more, the merrier (Fillmore et al. 1998).

Table 1. The syntax-lexicon continuum

\begin{tabular}{lll}
\hline Construction type & Traditional name & Examples \\
\hline $\begin{array}{l}\text { Complex and (mostly) } \\
\text { schematic }\end{array}$ & syntax & [SBJ be-TNS V-en by OBL] \\
Complex, substantive & subcategorization & [SBJ consume OBJ]
\end{tabular}




\begin{tabular}{lll}
$\begin{array}{l}\text { verb } \\
\text { Complex and (mostly) } \\
\text { substantive }\end{array}$ & $\begin{array}{l}\text { frame } \\
\text { idiom }\end{array}$ & {$[$ kick-TNS the bucket $]$} \\
$\begin{array}{l}\text { Complex but bound } \\
\text { Atomic and schematic }\end{array}$ & $\begin{array}{l}\text { morphology } \\
\text { syntactic } \\
\text { category }\end{array}$ & {$[$ [NOUN-s], [VERB-TNS $]$} \\
Atomic and substantive & word/lexicon & {$[$ this], [ green $]$} \\
\hline
\end{tabular}

The fact that the same construction can exist as both schematic and lexically filled has spurred several construction grammarians to assume that constructions are organized in lexicality-schematicity hierarchies in the "constructicon" (Croft 2003; Barðdal 2001a, 2006a, 2006b, 2008, 2010; Iwata 2008; Toft 2009). Argument structure constructions, for instance, can be seen as being organized into higher-level schematic constructions, event-type constructions, verb-class-specific constructions, verbsubclass-specific constructions, with verb-specific constructions at the bottom of the hierarchy (Barðdal 2001a, 2006a, 2006b, 2008, 2010a, 2010b).

Related constructions are sometimes organized into constructional families on the basis of their form and sometimes on the basis of their function or meaning. In our view, this is a major problem in constructional research, as it does not facilitate comparisons across individual linguistic studies, either language specific studies or studies of constructions across languages. There are several studies found in the literature, for instance, giving a combined account of the Resultative and the CausedMotion Construction (Rappaport Hovav and Levin 2001; Goldberg and Jackendoff 2004), under the unifying label Resultative Construction, while other studies take form as their point of origin (Bergen and Plauché 2001; Barðdal and Molnár 2003, Barðdal 2006a, 2007, 2008; Culicover 2008). We believe, however, that these two approaches can be regarded as reconcilable, specifically with the aid of lexicalityschematicity hierarchies, as these explicate the structure of individual subconstructions in a constructional network. That is, in a constructional network where the Resultative and the Caused-Motion Constructions are analyzed together on the basis of their function or semantics, a further explication of the internal structure of each of these is needed, and such an analysis can be carried out using lexicalityschematicity hierarchies.

Malchukov et al. (2007), in a manuscript entitled "Ditransitive Constructions: A typological overview," define ditransitivity in terms of meaning, i.e., as a three-place predicate denoting transfer, with an agent argument, a recipient-like argument and a patient-like argument. Observe that this definition of the ditransitive includes not only examples like John gave Bill a book, which is the prototypical ditransitive with a verb and two objects, but it also includes examples like John gave a book to Bill, as the prepositional object of give in the second example is a recipient. Also, as Malchukov et al. note themselves, this definition excludes examples like John built Bill a house, as there is no transfer involved. The present research, in contrast, emphasizes that there is much more to ditransitivity than only the concept of transfer (see Section 4 below).

Here we would like to stress the fact that an analysis into constructional families based on function or meaning presupposes that the meaning of a particular construction is known. For argument structure constructions, moreover, this entails a semantic analysis of the lexical items that instantiate a construction, as the meaning of semantically compositional argument structure constructions is generally regarded as being contingent upon the meaning of the individual lexical items which instantiate it 
(Goldberg 1995; Barðdal 2006a, 2008, 2010a). Therefore, semantic analyses of the lexical predicates which instantiate a construction in individual languages or language families must be carried out prior to analyses into constructional families based on meaning or function.

One of the aims of the present article is to investigate which function or semantics is found with the form most often associated with the Ditransitive Construction, i.e., Subj-V-IO-DO, in West-Scandinavian, i.e., Modern Icelandic, Modern Faroese, Modern Norwegian and Old Norse, as a follow-up of Barðdal's (2007) study where the case languages Modern Icelandic and Old Norse are compared with the Norwegian and Swedish dialects that maintained morphological case well into the 19th century. Barðdal's study did not compare the standard language of Norwegian, nor did it include Faroese. The present study aims to amend this and, as opposed to Barðdal (2007), it also includes an investigation of the various case patterns found between the indirect and the direct object, as there are five different case patterns found with the ditransitive form in the earlier West-Scandinavian languages, i.e., Dat-Acc, Dat-Dat, Acc-Dat, Acc-Gen and Dat-Gen (cf. Zaenen et al. 1985; Yip et al. 1987; Ottósson 1991; Holmberg and Platzack 1995; Kristoffersen 1998; Jónsson 2000; Maling 2002; Barðdal 2007). In this context we will also consider a special subconstruction of the Ditransitive Construction in Modern Norwegian, which we have labeled the V-REFL-NP Construction, as this construction has unique semantics associated with it, not found with the general Ditransitive Construction in Norwegian. Following Croft (2003) and his analysis of the Ditransitive Construction in English, we will suggest lexicality-schematicity hierarchies for the Ditransitive Construction in West-Scandinavian based on verb classes. Also, following recent typological research (Croft 2001; Haspelmath 2003; Malchukov et al. 2007) and comparative constructional work (Barðdal 2004, 2006a, 2007; Barðdal and Eythórsson 2010), we will render the semantics of the WestScandinavian Ditransitive Construction in terms of a semantic map.

\section{Delimitation of the present study}

In the transformational-generative framework of the 1960s, Barbara Hall (later B.H. Partee) proposed the analysis whereby ditransitive (V-NP-NP) sentences like He gave her a sweater are derived from an underlying V-NP-PP structure He gave a sweater to her (cf. Hall 1965: 58). Since a prepositional object (a "to-variant") was changed into an indirect "dative" object, this was called dative shift.

The two structural "alternants" in the proposed dative alternation were originally taken to have the same semantic properties, although since then several studies have pointed to instances where double object sentences and corresponding to-variants show differences in interpretation and are therefore not mutually exchangeable. Bresnan and Nikitina (2003: 3-4) note that many of these earlier semantically oriented studies contended that verbs and idioms with possessive semantics, i.e., when something comes into somebody's possession, are coupled to the V-NP-NP structure, while allative semantics, i.e., when something is moved to a location, is uniquely coupled to the V-NP-PP structure:

(2) a. 'x causes y to have $z$ ' (possessive semantics) $\rightarrow$ NP V NP NP

b. ' $x$ causes $z$ to go to/be at $y$ ' (allative semantics) $\rightarrow$ NP V NP PP 
In constructional terms, the two forms are paired with different semantics. In (3) below it is clear that the verb throw is compatible with either the possessive or the allative semantics of each of the two structures, while the verb lower has allative semantics and cannot be used for change of possession. If the two structures were semantically equivalent, one would expect both throw and lower to be able to occur with both of them. The fact, however, that lower is infelicitous with the V-NP-NP structure shows that the two forms are neither semantically equivalent nor interchangeable.

(3) a. I threw the box to John/I threw John the box.

b. I lowered the box to John $/{ }^{*}$ I lowered John the box.

Observe, moreover, that even though examples can be constructed where the two forms yield similar meaning, it is well known that a prepositional object is not always an option. The sentence He gave a hug to her may be regarded acceptable by some speakers, although the prepositional variant is unacceptable with give somebody problems (cf. Marantz 1993):

(4) a. He gave her problems.

b. *He gave problems to her.

From these and similar observations where the double object pattern and the prepositional pattern differ in semantics, it can be concluded that they are best treated as separate constructions (cf. Goldberg 2002, 2006: 26-33). Therefore, in this article we restrict our analysis to the Ditransitive Construction and leave out its possible prepositional paraphrase. With the term Ditransitive Construction we mean structures with two internal arguments, where both arguments are direct arguments of the construction. This definition excludes object predicates exemplified in "I pronounce you man and wife" where only you is a direct argument, while the second NP is a predication of you.

\section{Ditransitives in the West Scandinavian languages}

Goldberg (1995: 126) lists the following semantic subclasses for the English Ditransitive Construction (cf. also Pinker 1989; Levin 1993; Croft 2003):

(5) 1. Verbs of giving: give, pass, hand, lend, etc.

2. Verbs of instantaneous causation of ballistic motion: throw, toss, shoot, blast

3. Verbs of sending: send, mail, ship.

4. Verbs of continuous causation of accompanied motion: bring, take.

5. Verbs of future having: offer, promise, guarantee, etc.

6. Verbs of communicated message: tell, show, ask, read, etc.

7. Verbs of instrument of communication: e-mail, telegraph, wire, fax, etc.

8. Verbs of creation: bake, make, build, cook, sew, knit, etc.

9. Verbs of obtaining: get, buy, find, steal, win, earn, etc.

A semantic analysis of the Ditransitive Construction in Modern Icelandic, carried out by Barðdal (2007), reveals that the lexical scope of the construction is much wider in Icelandic than in English, at least according to the picture of English given in the 
literature. It seems to us that if one includes various features of non-Standard English, this language becomes more similar to the West-Scandinavian languages we are describing, but we have not undertaken a systematic study of the complete situation in English (see, however, some examples of non-Standard English in Section 4.7 and in Webelhuth and Dannenberg 2006 and the references cited there). In addition to verbs denoting actual, intended, retained and metaphorical transfer, listed in (5) above, verbs of transfer along a path, verbs of possession, utilizing, enabling, hindrance, constraining and verbs denoting mental activities are also instantiated by the Ditransitive Construction in Modern Icelandic, Old Norse, and the Norwegian and Swedish dialects which had still preserved the morphological dative when Reinhammar carried out her work on morphological datives in 1973, which included argument structure constructions.

At the same time, the Ditransitive Construction in Modern Icelandic and the before-mentioned Norwegian and Swedish dialects can only be instantiated by verbs of creation, like 'build', and obtaining, like 'buy', to a limited degree, as opposed to English, German and East Scandinavian, i.e., Swedish and Danish. Also, predicates denoting ballistic motion, like 'throw', cannot occur at all in the Ditransitive Construction in the standard North Germanic languages, in contrast to English and German (Barðdal 2007: 16-18), although this pattern may be confined to particle verbs in German.

This raises the question whether the lexical and the semantic range of the Ditransitive Construction has expanded in the history of West-Scandinavian but contracted in the other Germanic and East-Scandinavian languages, or whether the facts of the present-day languages reflect differences existing already before the beginning of recorded history. A comparison between text corpora from two different periods of Icelandic reveals that there is a substantial reduction of 42 percent in the type and text frequency of the Ditransitive Construction from Old Norse to Modern Icelandic (Barðdal 2007, 2009: 126-130). This decrease in the use of the Ditransitive Construction in Icelandic is concomitant with a restriction on the indirect object of verbs of creation and obtaining that it be reflexive. A similar decrease in the use and the frequency of the Ditransitive Construction has also been documented in Dutch (Colleman 2002). We provide a comprehensive analysis of the V-REFL-NP Construction in Section 5 below. In the remainder of this section, we will compare the semantics of the Ditransitive Construction in Modern Icelandic with the semantics of the construction in Modern Faroese, Modern Norwegian and Old Norse. Such a comparison should throw light on the issue of whether the semantic range of the construction has expanded in West-Scandinavian or whether these differences existed before the beginning of recorded history. We start by giving the facts of Modern Icelandic, before we proceed to the comparison with Modern Faroese, Modern Norwegian and their common predecessor, Old Norse.

\subsection{Icelandic}

Modern Icelandic counts ca. 150 predicates which select for the Dat-Acc case frame for the two objects, while the remaining four case frames are instantiated by 5-14 predicates each (Jónsson 2000; Barðdal 2007). Postponing the discussion of the four low type frequency case frames until the section on Old Norse, the current 150 Dat-Acc predicates divide across at least 17 narrowly-defined semantic verb classes (for a full overview of the lexical predicates instantiating the construction in Modern 
Icelandic, see Barðdal 2007):

(6) 1. Verbs denoting (prolonged) possession/owning: eiga sér e-ð 'have sth'

2. Verbs inherently denoting giving or delivering: gefa e-m e-ð 'give sby sth (as a gift)'

3. Verbs of lending: lána e-m e-ð 'lend sby sth'

4. Verbs of paying: borga e-m e- $\partial$ 'pay sby for sth'

5. Verbs of sending: senda e-m e- $\partial$ 'send sby sth'

6 . Verbs of bringing: bera e $m e-\partial$ 'bring sby sth'

7. Verbs of future transfer: bjóða e- $m e-\partial$ 'offer sby sth'

8. Verbs denoting transfer along a path: brjóta sér leið 'break oneself a passage'

9. Verbs of enabling: auðvelda e- $m e-\partial$ 'facilitate sth for sby'

10. Verbs of communicated message: kenna e- $m e-\partial$ 'teach sby sth'

11. Verbs of instrument of communicated message: smsa e-m e-ð' text sby sth'

12. Verbs of creation: blanda sér drykk 'mix a drink for oneself', rista sér e-ð 'toast sth for oneself'

13. Verbs of obtaining: ávinna sér e-ð 'acquire sth for oneself'

14. Verbs of utilizing: nota sér eitthvað 'use sth for oneself'

15. Verbs of hindrance: banna e- $m$ e- $\partial$ 'forbid sby (to do) sth'

16. Verbs of constraining: setja sér $e-ð$ 'determine (to do) sth', setja e-m e-ð fyrir 'give sby a task'

17. Verbs denoting mental activity: fyrirgefa e-m e-ð 'forgive sby sth', imynda sér $e-\partial$ 'imagine sth'

Observe that some of these classes have already been identified for English (some under different labels), while the others were established by Barðdal (2007) in her work on the semantic and lexical range of the Ditransitive Construction in Icelandic, compared to (North) Germanic. As these may not be familiar to readers with diverse non-Scandinavian backgrounds, we reproduce a few examples from each of the additional narrowly-circumscribed verb classes below: ${ }^{2}$

Dýr ... áttu sér

bústaði og fjölskyldur.

Possession

animals had themselves.DAT homes.ACC and families.ACC

'Animals ... had houses and families.'

(8) a. Баð var eitthvað að éta sér lei

there was something to eat itself.DAT way.ACC

inn $i$ eyrað á mér.

in to ear on me

'Something was eating its way into my ear.'

b. Höfuðiðvar tómt eins og glas frá kvöldinu áður. Engar

head was empty like a glass from evening before no

hugsanir, frumlegar eða öðruvisi, reyndu að brjóta sér

thoughts original or otherwise tried to break themselves.DAT

leið $i$ gegnum pykka punglyndisviði hugans.

way.ACC in through thick depression-woods mind

'My head was empty like a glass from the evening before. No thoughts, either original or others, tried to force their way through my mind's thick woods of depression.' 
(9) ... аð auðvelda honum hansalmennu störf...

Enabling

to facilitate him.DAT his general.ACC work.ACC

'... to make his job easier for him ...'

Deir hagnýttu sér eldspýtur og stálpenna. Utilizing they used themselves.DATmatches.ACC and steel-pens.ACC

'They exploited matches and pens.'

(11) ... að pessi aðstaða hafi hugsanlega byrgt honum sýn ... Hindrance that this situation has possibly blocked him.DAT view.ACC

'... that this situation may have blocked his view ...'

(12)a. Heilsufarið setti honum nokkrar skorður

Constraining

health set him.DAT some restrictions.ACC

með moetingar.

with attendance

'His health restricted his attendance.'

b. Britney hefur nú sett Paris stólinn fyrir dyrnar.

Britney has now set Paris.DAT stool-the.ACC for doors

'Britney has now given Paris an ultimatum.'

(13) Баð má hugsa sér pann möguleika að... Mental activity

there may think oneself.DAT that possibility.ACC that

'One can imagine the possibility that ...'

Moreover, as mentioned above, one English class is missing from Icelandic, i.e., verbs of ballistic motion, which cannot instantiate the Ditransitive Construction in Icelandic (see also Croft et al. 2001 on the different syntactic behavior of transfer of possession verbs across a typologically diverse range of languages, amongst others their ability to occur in the Ditransitive Construction):

(14)a. *Hann kastaði hundinum kexið/ kexinu.
he threw dog-the.DAT biscuit-the.ACC/biscuit-the.DAT
Intended meaning: 'He threw the dog the biscuit.'
b. *Hann sparkaði henni boltann/ boltanum.
he kicked her.DAT ball-the.ACC/ ball-the.DAT
Intended meaning: 'He kicked her the ball.'

It has been reported by Falk (1990: 72) that Swedish speakers disagree on the acceptability of such examples in Swedish, meaning that some speakers seem to accept it while others do not (acceptability marking original):

$$
\begin{aligned}
& \text { \#Han slängdehenne en handske. } \\
& \text { he threw her a glove }
\end{aligned}
$$

A closer inspection of the narrowly-circumscribed semantic classes in (6) above reveals that they fall into more general semantic categories. We suggest the following eight semantic relations between the verb classes, and hence a network of meanings 
associated with the Ditransitive Construction in Icelandic (cf. Figure 1 below with the original numbering of the 17 verb classes given in parenthesis):

\section{Actual Transfer}

Verb classes 2-5 above are all instantiations of the transfer schema, where an object is moved from one participant to another or one location to another. These can therefore be regarded as prototypical instances of the Ditransitive Construction. Verbs of giving and sending are the most general, whereas lending and paying are more specific ways of making a transfer. Verbs of bringing and obtaining, i.e., verb classes 6 and 13 above, also have a deictic aspect associated with them (cf. Goldberg 1995: 38) which is absent from the other verbs in this more general semantic category. We refer to them in Figure 1 as denoting DEICTICALLY DIRECTED TRANSFER.

\section{INTENTION}

Verb class 7 above contains verbs expressing intention, either intended transfer or other intentions. Goldberg (1995: 38) postulates two classes covering such verbs. One contains verbs like promise and guarantee ("verbs of giving with associated satisfaction conditions" in her terminology), the other with verbs of leaving, granting etc. (her "verbs of future transfer"). As several of the verbs in these classes are not restricted to intended transfer, we refer to this class as verbs of INTENTION in our analysis.

\section{CREATION}

Among verbs of creation (verb class 12) at least two different subtypes can be identified, i.e., verbs of creating, like blanda sér drykk 'mix oneself a drink', where something is literally created, and verbs which do not really entail creation of an object but do rather refer to the modification of an object. An example is rista sér e- $ठ$ 'toast oneself sth' where the substance referred to by the direct object is only modified and not created in the process denoted by the verb. We also analyze verb class 8 , containing verbs expressing transfer along a path, like brjóta sér leið 'break oneself a passage' as being a subclass of creation verbs, as the object is created incrementally during the process denoted by the verb. In the present example, the passage does not exist before the hewing process takes place, but comes into existence during that process.

\section{Mode OF COMMUNiCATION}

Several ditransitive verbs denote aspects of communication. In earlier research, as well as in the fine-grained semantic classification in (6) above, two different verb classes have been identified (classes 10 and 11). The first one includes verbs of communicated message, with meanings like 'tell', 'teach', 'show', and the other includes verbs of instrument of communication, with meanings like 'fax' and 'email'. In our analysis we subsume them into a more general semantic class, i.e., MODE OF COMMUNICATION, since they all describe various ways of communicating - one can communicate by telling a story, by sending someone an email, a text message, a fax, and so on. There is also an instrument involved in verbs of telling, namely the human voice.

\section{ENABLING}

This semantic category subsumes both verbs of enabling (verb class 9) and verbs of utilizing (verb class 14). The more general semantic class of ENABLING is not 
necessarily confined to predicates denoting enabling of transfer, but rather do they denote enabling, assistance and advantage in general. Verb meanings within this category include 'do somebody a favor', 'facilitate something for somebody' and 'make use of something for oneself.'

\section{RETAINING}

Verbs of retaining (verb class 15) have usually been discussed in the literature as necessarily retaining transfer. This, however, is not true, as there are several verbs of retaining in the West-Scandinavian languages which do not necessarily entail that transfer has been retained, with meanings like 'refuse', 'forbid' and 'make something difficult for somebody'. Some of the predicates denoting constraining (verb class 16) also fall into this class, like 'give somebody an ultimatum', while other verbs of constraining denote mental processes (see below).

\section{Mental Processes}

Verbs expressing mental activity (verb class 17) include both verbs which can be seen as denoting metaphorical transfer of mental attitudes, like fyrirgefa 'forgive', and metaphorical transfer of mental states, for example Norwegian erindre seg noe 'think (back) of sth'. Others simply denote mental processes like 'think' and 'imagine'. Some verbs of constraining (verb class 16) also signify mental processes, like setja sér e- $\partial$ 'determine (for oneself) to do something'.

\section{POSSESSION}

Verbs of (prolonged) possession (verb class 1) are verbs expressing meanings like 'own', 'save' and 'eke out' which can occur in the Ditransitive Construction with a reflexive object.

To summarize, the Ditransitive Construction in Icelandic is not only associated with the concept of transfer, i.e., actual, intended, metaphorical and retained transfer, as assumed in existing analyses of the English Ditransitive, but also with verbs denoting creation, mode of communication, enabling, retaining, mental processes and possession. As such, the earlier English-based analysis cannot be satisfactorily applied to Icelandic or the other West-Scandinavian languages. In order to illustrate this we now turn to the lexical and semantic range of the Ditransitive Construction in Faroese. 


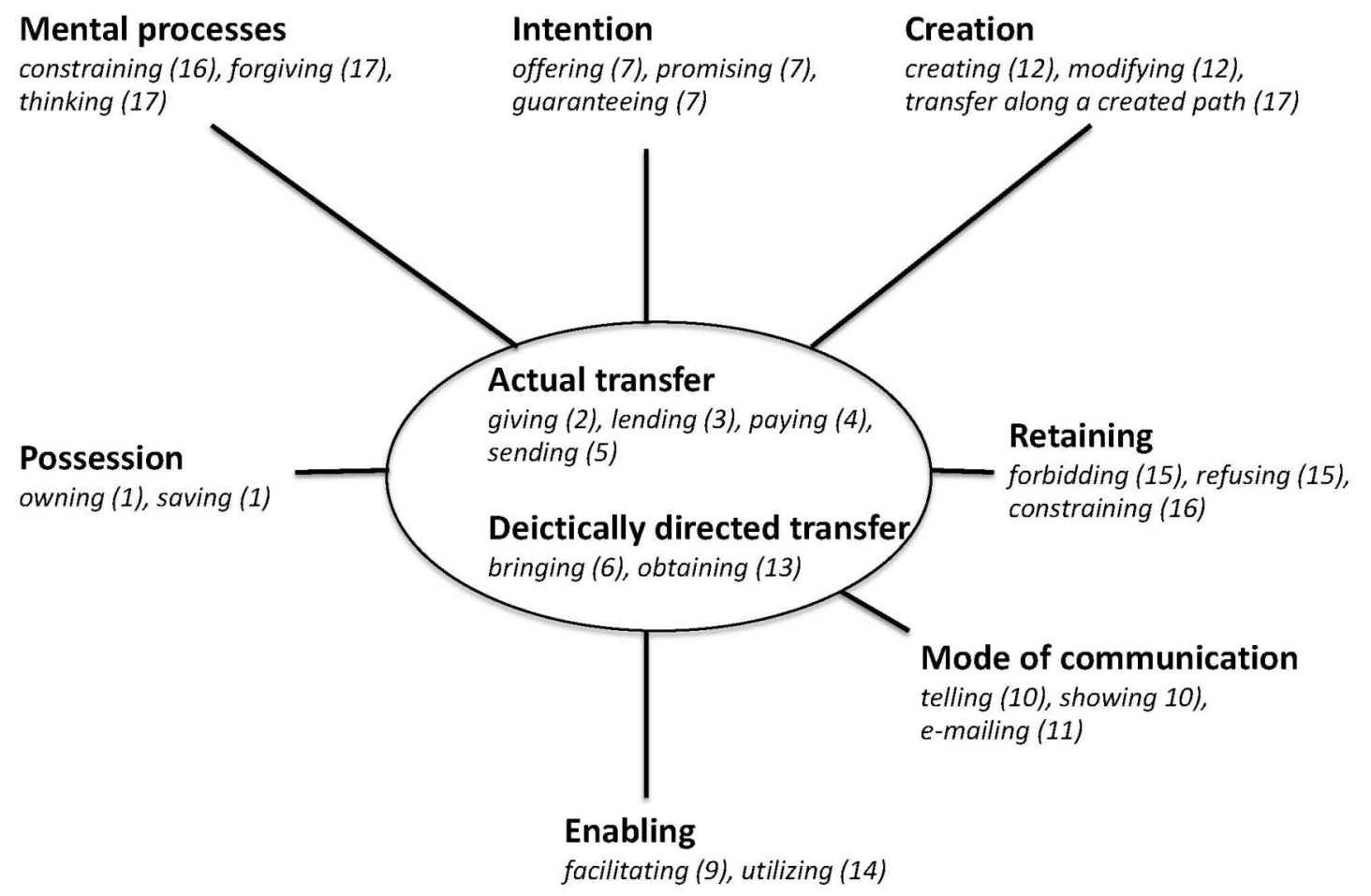

Figure 1. The semantics of the Ditransitive Construction in Icelandic

\subsection{Faroese}

Faroese, another West-Scandinavian language spoken on the Faroe Islands, has existed as a written language since 1850. There is a high degree of Faroese-Danish bilingualism on the Faroes. This may have contributed to the breakdown of the case system, as a high degree of contact with another language favors the case and argument structure constructions highest in type frequency and disfavors the ones lowest in type frequency. Such a process may gradually cause low type frequency constructions to fall into disuse (cf. Barðdal 2008: Ch. 6, 2009). Faroese has, moreover, lost its morphological genitive with verbs (Thráinsson et al. 2004) and the morphological dative has also been heavily reduced during the last centuries, since the beginning of written records (Malmsten 2001; Jónsson 2009).

The Ditransitive Construction in Faroese has maintained two case frames, i.e., the Dat-Acc, for the majority of ditransitive predicates, and Acc-Acc for a handful of others (Thráinsson et al. 2004: 62, 433). The Dat-Acc predicates fall into the following general semantic categories (examples are from FTS: Føroyskt TextaSavn 'Faroese Text Collection', Thráinsson et al. 2004, complemented with data from Faroese sites on the World Wide Web):

\section{Actual Transfer}

2. Verbs inherently denoting giving or delivering: geva e-m nakað 'give sby sth'

3. Verbs of lending: loena e-m nakað 'lend sby sth'

4. Verbs of paying: løna e-m nakað 'pay, repay sby sth'

5. Verbs of sending: senda e-m nakad 'send sby sth'

6. Verbs of bringing: bera e-m nakad 'bring sby sth'

13. Verbs of obtaining: fáa e-m nakad 'get sby sth'

\section{INTENTION}


7. Verbs of future transfer: lova e-m nakað 'promise sby sth'

\section{CREATION}

8. Verbs denoting transfer along a path: brjóta saer veg 'break oneself a passage'

12. Verbs of creation: gera scer nakað 'make sth for oneself'

\section{Mode OF COMMUNICATION}

10. Verbs of communicated message: skriva e-m nakað 'write sby sth'

11. Verbs of instrument of communication: maila e-m nakað 'e-mail sby sth'

\section{ENABLING}

9. Verbs of enabling: lova e-m nakad 'permit sby sth'

14. Verbs of utilizing: nýta scer nakað 'make use of sth for oneself'

\section{RETAINING}

15. Verbs of hindrance: banna e-m nakað 'forbid sby sth'

16. Verbs of constraining: seta e-m nakad fyri 'give sby a task', seta stólin fyri hurðina 'give sby an ultimatum'

\section{Mental PRocesses}

17. Verbs denoting mental activity: fyrigeva e-m nakad 'forgive sby sth', imynda scer nakad 'imagine sth'

\section{Possession}

1. Verbs denoting (prolonged) possession/owning: goyma scer nakað 'save sth for oneself'

This overview of ditransitive predicates in Modern Faroese shows that the 17 narrowly-circumscribed verb classes found in Icelandic are also found in Faroese, including verbs denoting not only transfer, but also creation, communication, enabling, retaining, mental processes and possession. As a consequence, the semantic map of the Ditransitive Construction in Icelandic, shown in Figure 1 above, is also valid for Faroese. We now proceed to the lexical and the semantic range of the Ditransitive Construction in Standard Modern Norwegian.

\subsection{Norwegian}

The Proto-Scandinavian case system with four morphological cases has gone lost in the history of Norwegian. In the contemporary Norwegian language, there are remnants of a case distinction between a subject and an object form of the pronouns, but not all the way through the system. Probably all varieties of Norwegian distinguish morphologically between subject and object in first person singular, and most varieties make a distinction in second person singular. But there is a "hierarchical decline" here, and today very few dialects have any distinction in the second person plural. With such a collapse of the case system except for these pronominal remnants, the five different case constructions of the Ditransitive Construction found in Old Norse and Modern Icelandic have merged into one construction. The predicates can be divided into the following general semantic categories (Examples are from: a) introspection, b) the World Wide Web, and c) 
Norsk talespråkskorpus - Oslodelen 'Oslo Corpus of Spoken Norwegian'):

\section{ACtual Transfer}

2. Verbs inherently denoting giving or delivering: gi noen noe 'give sby sth (as a gift)', donere noen noe 'give sby sth (as a donation)' rekke noen noe 'hand sby sth'

3. Verbs of lending: låne noen noe 'lend sby sth'

4. Verbs of paying: betale noen noe 'pay sby sth'

5 . Verbs of sending: sende noen noe 'send sby sth'

6. Verbs of bringing: (over)bringe noen noe 'bring sby sth (over)'

13. Verbs of obtaining: skaffe noen noe 'get sby sth'

\section{INTENTION}

7. Verbs of future transfer: love noen noe 'promise sby sth', tilby noen noe 'offer sby sth', forespeile noen noe 'give sby (false) expectations about sth'

\section{CREATION}

8. Verbs denoting transfer along a path: brøyte seg vei 'break oneself a passage'

12. Verbs of creation: koke seg noe 'boil oneself sth'

\section{Mode of COMMUNiCATION}

10. Verbs of communicated message: forklare noen noe 'explain sth for sby'

11. Verbs of instrument of communication: meile noen noe 'e-mail sby sth'

\section{ENABLING}

9. Verbs of enabling: gjøre noen en tjeneste 'do sby a favor'

14. Verbs of utilizing: nyttiggjøre seg noe 'use sth to one's own advantage'

\section{RETAINING}

15. Verbs of hindrance: forby noen noe 'forbid sby (to do) sth'

16. Verbs of constraining: pålegge noen noe 'impose sth on sby'

\section{Mental Processes}

17. Verbs denoting mental activity: forestille/innbille seg noe 'imagine sth', erindre seg noe 'think (back) of sth'

Observe that verbs of possession do not instantiate the Ditransitive Construction in Norwegian, as opposed to in Icelandic and Faroese, at least not in the possession sense. That is, verbs of having can be used in the Ditransitive Construction in Norwegian in the sense of obtaining, not possession. Therefore, De ville ha seg barn means 'They wanted to get children' and Vi skal ha oss ny bil snart means 'We are about to get us a new car soon', which is why the adverb snart 'soon' is fully combinable with $h a$ 'have' in this last sentence. It also seems that the obtaining sense with verbs of possession may be restricted to modal contexts.

Some of the verb classes which are low in type frequency in Modern Icelandic, like verbs of enabling, retaining and transfer along a path, are only instantiated by a couple of verbs in Norwegian. And as in both Icelandic and Faroese, several of the predicates can only occur with a reflexive indirect object.

To summarize, the semantics of the Ditransitive Construction in Norwegian is a subset of the semantics of the construction in Icelandic and Faroese, with the 
POSSESSION category excluded (see Figure 2). We finalize our analysis of the WestScandinavian languages with an overview of ditransitives in the language that Icelandic, Faroese and Norwegian stem from, i.e., Old Norse.

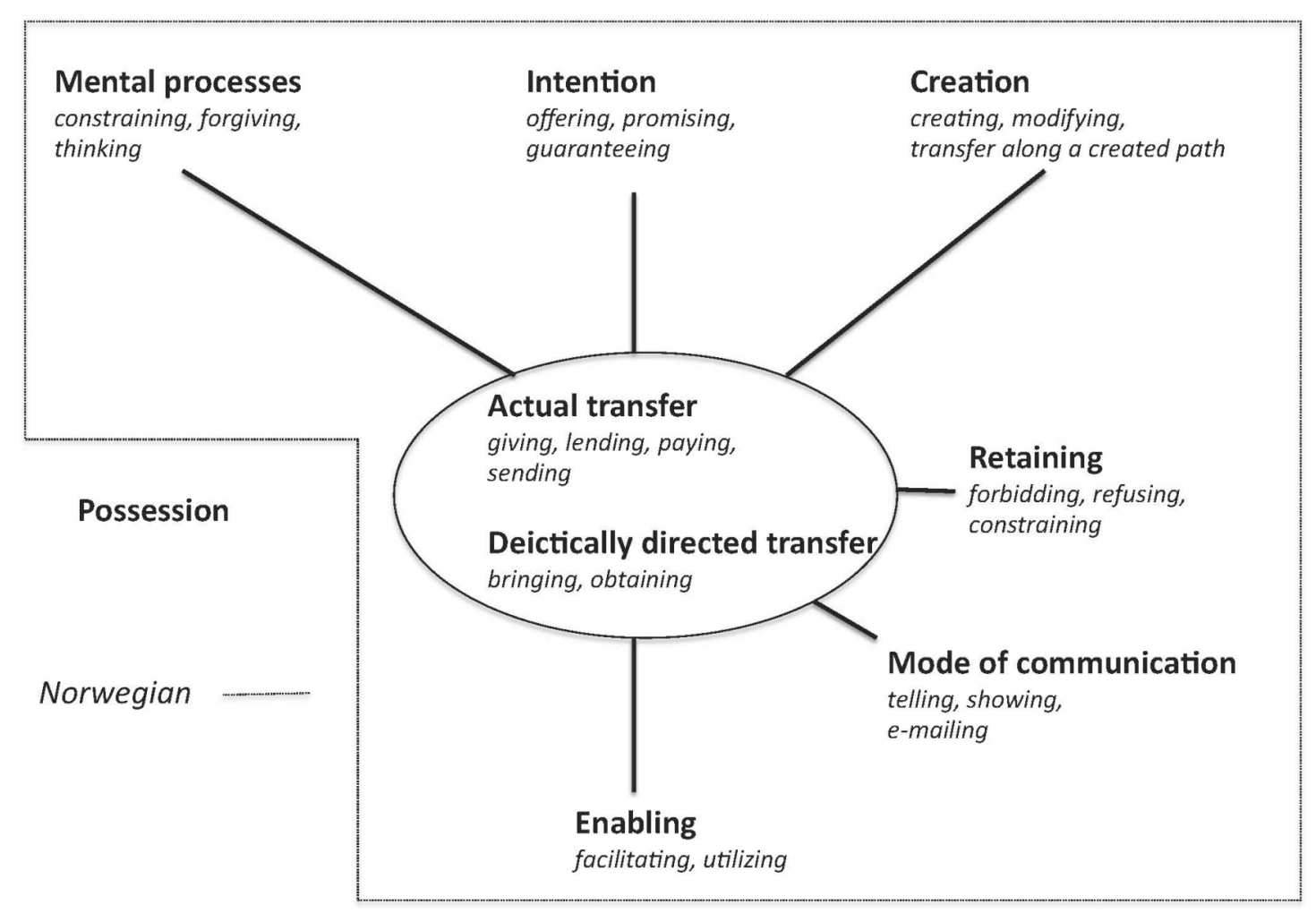

Figure 2. The semantics of the Ditransitive Construction in Norwegian

\subsection{Old Norse}

The language spoken in Scandinavia from the Viking period until ca. 1350 can be divided into two, Old East Scandinavian and Old West Scandinavian. Old East Scandinavian is the language that was spoken in Denmark and Sweden, while Old West Scandinavian is the language that was spoken in Iceland, the Faroe Islands and Norway, in addition to settlements in Greenland, Ireland and Scotland. Old West Scandinavian is also referred to in the literature as Old Norse, Old Icelandic, Old Norwegian or Old Norse-Icelandic.

Table 2. Type frequency of the five subconstructions of the Ditransitive Construction in Old Norse

\begin{tabular}{lc}
\hline Case frame & Type frequency \\
\hline Dat-Acc & 140 \\
Acc-Dat & 43 \\
Acc-Gen & 22 \\
Dat-Gen & 15 \\
Dat-Dat & 12 \\
\hline
\end{tabular}

Our Old Norse data set on the Ditransitive Construction has been compiled on the basis of an electronic version of Fritzner's Old Norse dictionary Ordbog over det gamle norske Sprog (1886-1896), supplemented with data from Barðdal (2007) based 
on Old Norse texts. As already stated above, the Ditransitive Construction in Old Norse divides across five different case frames, of which the Dat-Acc subconstruction is the one highest in type frequency. As evident from Table 2, there are approximately 140 Dat-Acc predicates in Old Norse, while the remaining four subconstructions are instantiated by $12-43$ predicates each. We start with an overview of the Dat-Acc construction, before proceeding to the remaining four subconstructions.

4.4.1. Dat-Acc subconstruction. Consider first the predicates that occur in the DatAcc subconstruction in Old Norse, the verb classes they belong to, and the more general semantic categories they instantiate:

\section{ACtUAL TRAnSFER}

2 . Verbs inherently denoting giving or delivering: gefa e-m e-t 'give sby sth'

3. Verbs of lending: ljá e- $m e-t$ 'lend sby sth'

4. Verbs of paying: launa $e-m e-t$ 'retaliate, repay sby sth'

5. Verbs of sending: senda e-m e-t 'send sby sth'

6 . Verbs of bringing: fora e-m e-t 'bring sby sth'

13. Verbs of obtaining: kaupa e-m e-t 'buy sby sth'

2. INTENTION

7. Verbs of future transfer: huga e-m e-t 'intend sth for sby'

\section{CREATION}

12. Verbs of creation: skera e-m e-t 'cur, sew sby sth'

\section{Mode OF COMMUNICATION}

10. Verbs of communicated message: kenna e-m e-t 'teach sby sth'

5. ENABLING

9. Verbs of enabling: láta $e-m e-t$ 'allow sby sth'

14. Verbs of utilizing: nýta sér $e-t$ 'utilize sth for oneself'

\section{RETAINING}

15. Verbs of hindrance: banna e-m e-t 'forbid sby sth'

16. Verbs of constraining: leiða e-m e-t 'make sby dislike sth'

\section{Mental Processes}

17. Verbs denoting mental activity: likna e-m e-t 'forgive sby sth'

\section{POSSESSION}

1. Verbs denoting (prolonged) possession/owning: spara sér e-t 'save sth for oneself'

As evident from this overview, two of the verb classes found in the Modern WestScandinavian languages are not found in the Old Norse material. These are verbs denoting transfer along a path and verbs of instrument of communication. As all the verbs of instrument of communication, with meanings like 'fax', 'e-mail', 'text', have come into existence as a result of recent technological advancements (Barðdal 2008: 119), it is not expected to find such predicates at all in the earlier stages of West- 
Scandinavian, let alone in the Ditransitive Construction. This is therefore a genuine extension of the ditransitive semantics, perhaps influenced by English.

The fact that verbs denoting transfer along a path are not found in Old Norse may be due to an accidental gap in the material passed on to us. Predicates of this type exist not only in the Modern West-Scandinavian languages, but also in Modern East Scandinavian and West Germanic:
(16)a. ... og begyndte at bryde sig vej ind gennem taget. Danish and started to break self way in through roof
'... and started to break their way through the roof.'

b. ... att bana sig väg genom gyttja.

Swedish

to break self way through mud

'... to break their way through the mud.'

c. Um sich einen Weg zu bahnen.

German

in-order self.DAT a way.ACC to break

'In order to plow one's way.'

d. ... often having to hew myself a passage with my axe. English

This subconstruction of the Ditransitive Construction is presumably the source, or at least one of the sources, of the English Way Construction, exemplified in the translations above, which according to Israel (1996) has its roots as far back as 14th century English. Given the existence of such constructions in the modern Germanic languages as well as in Middle English, it would be unexpected if this subconstruction of the Ditransitive Construction did not exist in Old Norse. On the basis of this comparative evidence, we opine that lack of examples of verbs denoting transfer along a path in the Ditransitive Construction in Old Norse is presumably an accidental gap in the data. Given these facts, the semantic range of the Ditransitive Construction has remained remarkably stable from Old Norse to the Modern West-Scandinavian languages, with the only addition that the Ditransitive Construction has been extended to verbs of instrument of communication. Therefore, the semantic map in 1, with the exception of verbs of instrument of communication, is also valid for Old Norse. We now turn to the four low type frequency subconstructions of the Ditransitive Construction in Old Norse, Acc-Dat, Acc-Gen, Dat-Gen and Dat-Dat.

4.4.2. Low type frequency Ditransitive case constructions. One example of each of the four low type frequency case constructions in Old Norse is given in (17) below, in descending order:

(17)a. Hún jós sveininn vatni ...

Acc-Dat

she scooped boy-the.ACC water.DAT

'She poured water over the boy ...' (Bárðar saga Snæfellsáss 1987: 60)

b. En pó vil eg yður pess biðja að...

Acc-Gen

but though will I you.ACC it.GEN ask to

'However, I will ask that of you to ...'

(Pormóðar páttur (eftir Flateyjarbók) 1987: 2275) 
c. Prándur synjaði honum ráðsins.

Dat-Gen

prándur denied him.DAT option-the.GEN

'Prándur denied him that option.' (Flóamanna saga 1987: 742)

$\begin{array}{ll}\text { d. ... og hét honum sinni vináttu ... } & \text { Dat-Dat } \\ \text { and promised him.DAT his friendship.DAT } \\ \text { '... and promised him his friendship ...' }\end{array}$

(Bjarnar saga Hítdælakappa 1987: 86)

We emphasize that the semantic typology developed by Barðdal (2007) and here further refined into eight more general semantic categories of ACTUAL TRANSFER, INTENTION, CREATION, MODE OF COMMUNICATION, ENABLING, RETAINING, MENTAL PROCESSES and POSSESSION should also be valid for the four low type-frequency case constructions in Old Norse, i.e., if our semantic categorization and semantic map is to have any predictability at all (cf. Croft's 2001: 96 Semantic Map Connectivity Hypothesis). Let us now consider the predicates instantiated by these case constructions, and hence their semantic range.

4.4.2.1. Acc-Dat verbs. Examples of Acc-Dat verbs are attested in Old Norse in two of the semantic categories:

\section{CREATION}

Verbs of creation: auka 'increase sth with sth', blanda 'mix sth with sth', búa 'decorate sth with sth', draga 'cover sth with sth', dreifa 'smear sth with sth', gyrða 'span, harness sth with sth', hlaða 'fill sth with sth', hverfa 'surround sth with sth', leggja 'cover sth with sth', setja 'coat sth with sth', skipa 'equip sth with sth', støkkva 'splash sth with sth'

\section{RETAINING}

Verbs of hindrance: afeira 'take sth from sby', affletta 'remove sth from sby', afdoema 'condemn sth from sby', firra 'remove sth from sby', halda 'keep sth from sby', leyna 'hide sth from sby', nema/ncema 'take sth from sby', rcena 'rob sth from sby', stela 'steal sth from sby'

Recall from Section 4.1 that the semantic category of CREATION also includes verbs expressing that the object has been modified, which is at issue with Acc-Dat verbs in Old Norse. Observe furthermore that our semantic category RETAINING also covers what for instance Goldberg (2002) describes as "Agent causes Possessor to lose Patient" and may be referred to as dispossession (cf. the discussion of dispossession in Colleman and De Clerck 2008: 204-205).

4.4.2.2. Acc-Gen verbs. Examples of Acc-Gen verbs are attested in Old Norse in two of our semantic categories, although only one of the semantic category is the same as with Acc-Dat verbs, i.e., RETAINING.

\section{Mode OF COMMUNiCATION}

Verbs of communicated message: eggja 'incite sby to sth', fy'sa 'incite sby to sth', hvetja 'incite sby to sth', spyrja 'ask sby about sth', frétta 'ask sby about sth', fregna 'ask sby about sth', biðja 'ask sby about sth', beiða 'demand sth 
of sby', krefja 'demand sth of sby', kveðja 'demand sth of sby', cesta 'demand sth of sby'

\section{RETAINING}

Verbs of hindrance: $d y l j a$ 'hide sth from sby'

4.4.2.3. Dat-Gen verbs. Examples of Dat-Gen verbs are attested in Old Norse in four of the relevant semantic categories:

\section{ACTUAL TRANSFER}

Verbs inherently denoting giving or delivering: fá e-m e-s 'give sby sth'

Verbs of lending: ljá $e-m$ e-s 'lend sby sth'

Verbs of obtaining: afla e-m e-s 'get sby sth', leita e-m e-s 'get sby sth'

INTENTION

Verbs of future transfer: vaena e-m e-s 'promise sby sth'

\section{RETAINING}

Verbs of hindrance: synja e-m e-s 'deny sby sth'

\section{Mental Processes}

Verbs denoting mental activity: ceskja e-m e-s 'wish sth for sby', unna e-m e-s 'not begrudge sby sth'

4.4.2.4. Dat-Dat verbs. Finally, examples of Dat-Dat verbs are attested in Old Norse in four of the semantic categories, of which three are the same as with Dat-Gen verbs, i.e., ACTUAL TRANSFER, INTENTION and RETAINING.

\section{ACTUAL TRANSFER}

Verbs of paying: bota $e-m e-u$ 'pay sby sth as fines', launa $e-m e-u$ 'pay sby sth'

\section{INTENTION}

Verbs of future transfer: heita $e-m e-u$ 'promise sby sth', lofa $e-m e-u$ 'promise sby sth'

\section{Mode OF COMMUNICATION}

Verbs of communicated message: svara e-m e-u 'answer sby sth', ógna e-m $e-u$ 'threaten sby with sth'

\section{RETAINING}

Verbs of hindrance: neita e-m e-u 'deny sby sth'

4.4.3. Semantic comparison. The semantic scope of each of the five subconstructions of the Ditransitive Construction is given in Figure 3. Observe that the different subconstructions all occupy adjacent regions in our ditransitive space. In other words, the semantic typology developed by Barðdal (2007) for Modern Icelandic, and here refined into eight more general semantic categories, has now been shown to be applicable to all the West-Scandinavian languages, both modern and ancient. It has 
moreover been proven to be valid for additional subconstructions of the Ditransitive Construction, which were not included in the original data set, and hence were not taken into account when the semantic typology was developed. As such, our semantic map fulfills the requirement that a language-specific and a construction-specific category should occupy adjacent regions in semantic space, according to Croft's Semantic Map Connectivity Hypothesis (2001: 96) It remains of course to be seen whether the validity of our semantic map can be sustained by other languages not genetically related to Germanic.

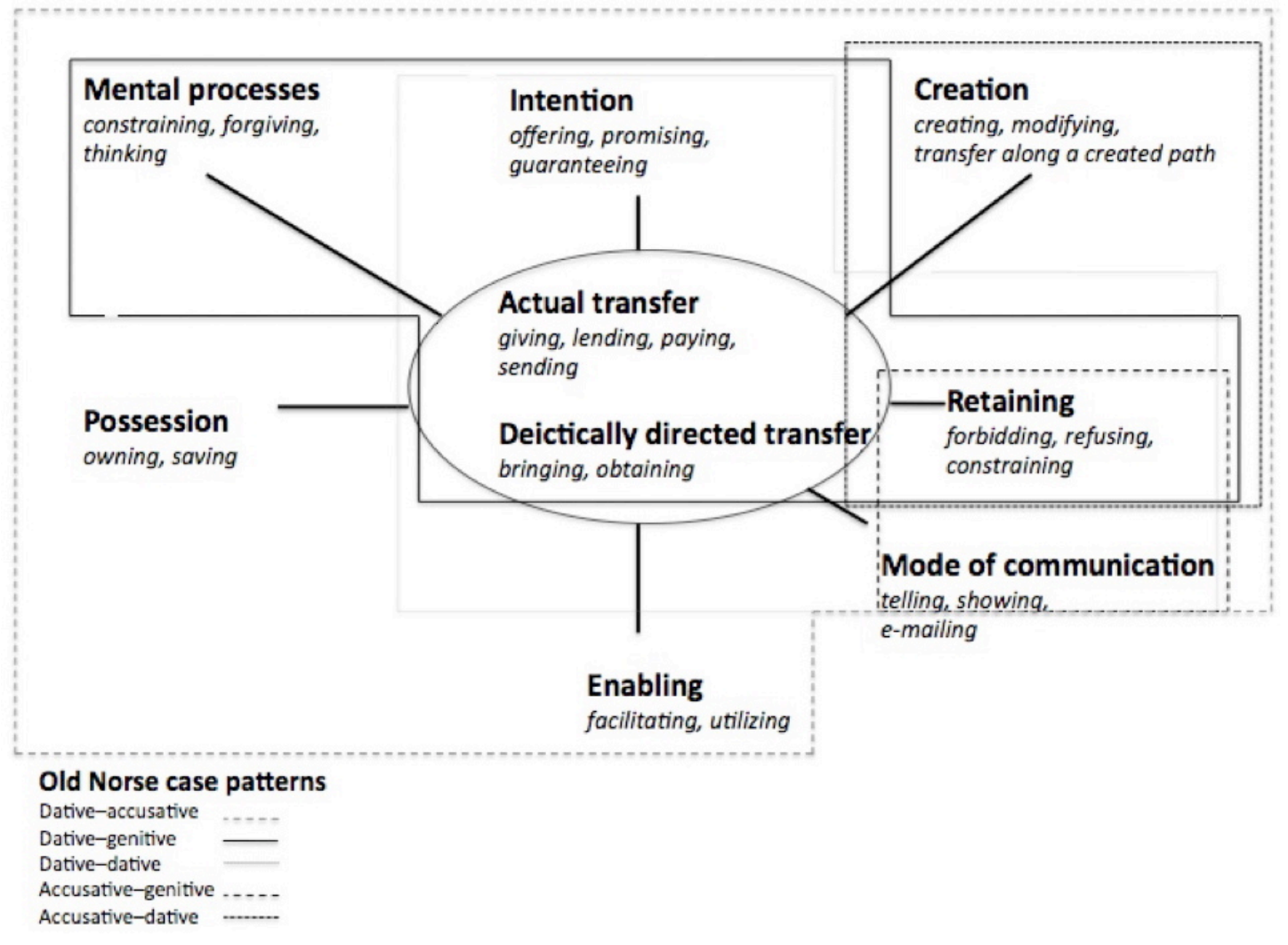

Figure 3. The semantic scope of the five different case constructions of the Old Norse Ditransitive Construction

Observe also that there is both a semantic overlap across the four low type frequency case constructions, as pointed out above, and a semantic overlap between the four and the high type frequency Dat-Acc construction in Old Norse. This partial synonymy is also manifested in the fact that several predicates can occur in more than one of the case constructions of the Ditransitive, like $f a$ ' 'give', for instance, which can instantiate both the Dat-Acc and the Dat-Gen subconstruction. It is argued by Barðdal (2008: Ch. 6,2009 ), for intransitive and transitive case and argument structure constructions, that such partial synonymy may contribute to the breakdown of case and alignment systems. As the case system of Proto-Scandinavian has been completely demolished in Norwegian, as well as in the East Scandinavian languages, Swedish and Danish, and substantially reduced in Faroese, this claim is further supported by the present ditransitive material. In Icelandic, in contrast, the predicates instantiating the low type frequency constructions have been maintained, which in turn may contribute to the perseverance of their low type frequency case patterns. 


\subsection{The semantic space of the West-Scandinavian Ditransitive Construction}

Figure 4 presents a combined semantic map for the four West-Scandinavian languages investigated in previous sections, including the five different subconstructions of Old Norse. Observe that Icelandic and Faroese occupy the same semantic space on the map, that the semantic map for Norwegian excludes verbs of possession, while the semantic map for the Dat-Acc construction in Old Norse excludes verbs of instrument of communication. The semantic space occupied by the four low type frequency subconstructions of the Ditransitive in Old Norse is also marked on the map. Observe also that each of the four subconstructions occupies adjacent regions on the map. Whether or not this adjacency is suggestive of a possible implicational hierarchy will bear on further data from more languages and in particular from languages not genetically related to the Germanic languages. This, however, is outside the scope of the present article.

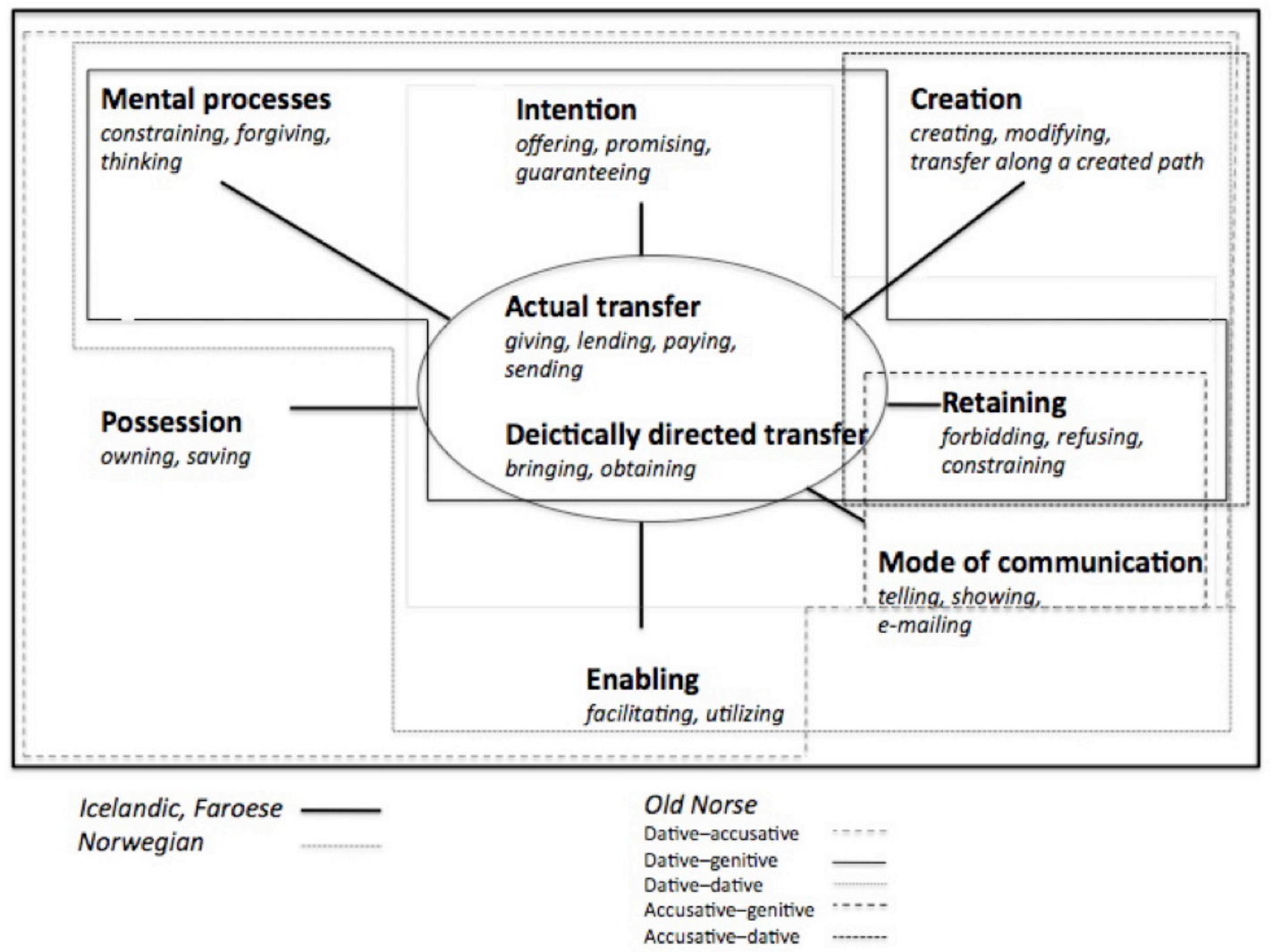

Figure 4. The delimitation of the Ditransitive Construction in West-Scandinavian in semantic space

\subsection{The lexicality-schematicity hierarchy of the Ditransitive Construction}

To complete the present analysis of the Ditransitive Construction in WestScandinavian, we suggest that the structure of the Ditransitive Construction can be modeled in terms of a lexicality-schematicity hierarchy, originally suggested by Croft (2003) for the Ditransitive Construction in English (see also Barðdal 2001a, 2006a, 2006b, 2008; Iwata 2008 and Toft 2009 on lexicality-schematicity hierarchies). 
We suggest the lexicality-schematicity hierarchy in Figure 5, where the topmost level of the hierarchy represents the most schematic level of the construction, i.e., the one which specifies the form of the construction, $\mathrm{V}-\mathrm{O}_{\mathrm{i}}-\mathrm{O}_{\mathrm{d}}$, and, at best, the meaning of the construction in terms of relational meaning. The level below the highest level represents the general semantic categories of ditransitives suggested above, i.e., ACTUAL TRANSFER, INTENTION, CREATING, MODE OF COMMUNICATION, ENABLING, RETAINING, MENTAL PROCESSES and POSSESSION. The level below that represents the level of the 17 narrowly-circumscribed semantic verb classes, i.e., verbs of possession, giving/delivering, lending, paying, sending, bringing, future transfer, transfer along a path, enabling, communicated message, instrument of communicated message, creation, obtaining, utilizing, hindrance, constraining, and mental activity. This is the level of verb-class-specific constructions. The level below this level contains verb-specific constructions, i.e., the individual verbs together with their verbspecific argument structure constructions. This is the level where idiosyncrasies in argument linking are encoded, i.e., by defining for each argument structure construction in each language which predicates can instantiate it. Due to space limitations, not all details of the hierarchy can be spelled out here.

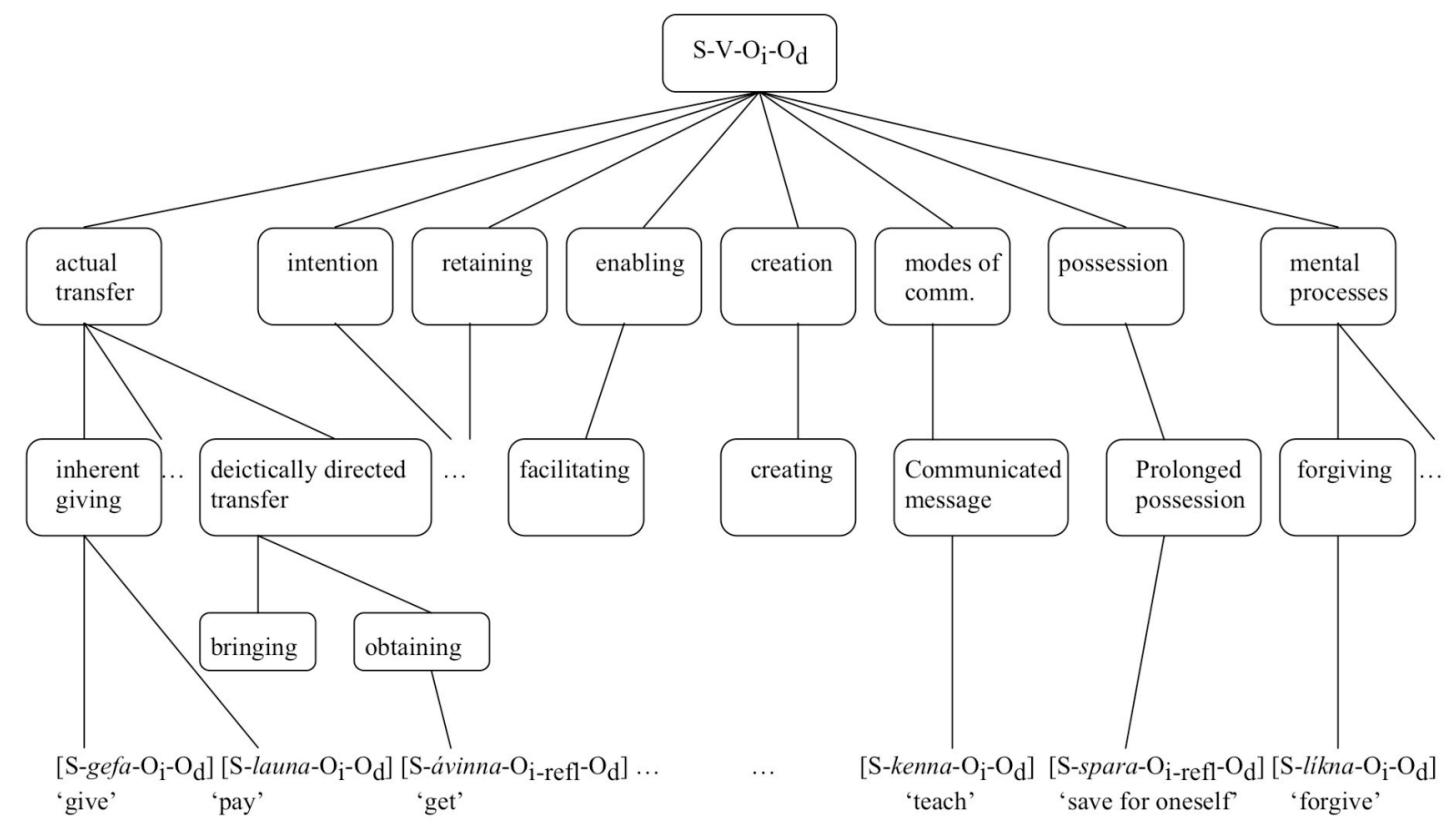

Figure 5. The lexicality-schematicity hierarchy of the Ditransitive Construction in the West-Scandinavian languages

One of the well-known problems in research on argument structure relates to lexical idiosyncrasy. That is, the occurrence of verbs in argument structure constructions is not necessarily directly predictable from their semantic class (cf. Croft 1998). Pinker (1989), for instance, points out that the verb explain is infelicitous in the Ditransitive Construction in English, even though verbs of communicated message constitute one subconstruction of the Ditransitive in that language. The same is true for the verb donate which, in spite of being a near-synonym to the verb give cannot occur in the Ditransitive Construction in English. In Norwegian, as opposed to Icelandic and English, the verb forklare 'explain' is frequently found in the Ditransitive Construction and the verb donere 'donate' can also be used ditransitively. Idiosyncrasies of this type can easily be captured with lexicality-schematicity hierarchies, as verb-specific constructions have a natural place there. As higher level 
generalizations, like which verb classes instantiate which construction, are also encoded in lexicality-schematicity hierarchies, the encoding of the lowest most idiosyncratic level does not take place at the cost of higher-level generalizations. In other words, both idiosyncratic verb-specific behavior and higher-level generalizations are preserved in this model. Lexicality-schematicity hierarchies therefore provide a model of the interaction between the grammar and the lexicon, i.e., they are structured inventories of lexicon-grammar interactions. Lexicalityschematicity hierarchies are thus the ideal tool for research in lexical typology which, as noted by Koptjevskaja-Tamm (2008), is in severe need for improving its methods and representational framework.

\subsection{Interim summary}

To summarize our findings so far in this article, we have shown that the semantic typology of the Ditransitive Construction, originally developed by Barðdal (2007) on the basis of Modern Icelandic, and here further semantically refined, is well applicable to Modern Faroese, Modern Norwegian, as well as to the five different case constructions of the Ditransitive Construction in Old Norse. It remains of course to be investigated whether this semantic typology is of further typological validity for genetically non-related languages.

We conclude that both the lexical and the semantic range of the Ditransitive Construction in West-Scandinavian has remained remarkably stable during the last thousand years. Moreover, our research on the West-Scandinavian Ditransitive is of imperative value, as it has revealed a clear need for a revision of earlier analyses of the semantics of the Ditransitive Construction, which are first and foremost based on data from Standard English. This claim is supported by the fact that several of the verb classes found in West-Scandinavian, and not hitherto included in any analyses of the West-Germanic languages that we know of, are easily found in both vernacular English and Standard German, given in (18-19) below, emphasizing our point from Section 4 above that dialectal data need to be taken into account:

(18)a. Molyneux wants critics to do him a favour.

Enabling

b. ... you are not intending to do him any harm so

Hindrance thank you?

c. ... often having to hew myself a passage with my axe.

Transfer along a path

d. Pasteur owned himself a vineyard and did several Possession experiments about alcoholic fermentation and improvement of wine and beer production. (www.crwflags.com/fotw/flags/fr-39-ar.html)

e. I owned me a '72 DS Station Wagon with "four on the tree-" ... (http://blog.wired.com/cars/2007/09/confessions-of-.html)

f. If I owned me a car, I would drive it so fast that they'd throw me in jail. (http://www.lyricsmania.com/lyrics/devin_davis_lyrics_22354/other_lyrics_52 980/moon_over_shark_city_lyrics_550970.html) 


\author{
(19)a. Dabei ermögliche ich ihm eine sorglose Enabling \\ through-that facilitate I him.DAT a.ACC sorrowless \\ existenz... \\ existence \\ 'Through that I make a sorrow free existence possible for him ...' \\ b. ... für dieses Ziel nutze ich mir den sportlichen Utilizing \\ for that goal use I me.DAT the.ACC sporty \\ Ausgleich. \\ equalizer \\ '... for that purpose I make use of the sporty equalizer.'
}

The existence of such examples in (vernacular) English and Standard German further corroborates the validity of our ditransitive semantic space, shown in Figures 1-4, within the domain of the Germanic languages. The present research also reveals a need for more cross-linguistic work within lexical typology, which is fundamental for all comparative constructional work. With these words we conclude our discussion of the lexical and semantic scope of the Ditransitive Construction in the WestScandinavian languages and turn instead to a specific, semantically noncompositional subconstruction in Norwegian, i.e., the V-REFL-NP Construction.

\title{
5. The Norwegian V-REFL-NP Construction: "å ta seg en øl" "treat oneself to a beer'
}

In this section we begin with a general discussion of the reflexivity constraint in the West-Scandinavian languages, before we turn to the semantically specific V-REFLNP Construction in Norwegian. We show that certain aspects of the syntactic behavior of this construction are idiosyncratic, not derivable from any general syntactic or grammatical rules of Norwegian. We show, moreover, that the semantics of the construction is specific or non-compositional, not derivable from the meaning of the parts. We conclude that a constructional analysis is needed in order to account for both the syntactic and the semantic facts of the Norwegian V-REFL-NP Construction.

\subsection{The reflexivization constraint in West-Scandinavian}

As already mentioned in previous sections, a subset of verbs of obtaining and creation in the West-Scandinavian languages are only felicitously used with a reflexive indirect object. The Icelandic verb of obtaining kaupa 'buy' is one of these verbs (20), whereas another Icelandic verb of obtaining útvega 'get' can also be used nonreflexively (21). The same contrast is found internally for verbs of obtaining, like with kjøpe 'buy' and skaffe 'get' (22-23), in the majority of Norwegian dialects (but see the discussion of example (24) below):

\footnotetext{
Jón Ásgeir keypti sér/ *henni/ *konunni ibúð í Jón Ásgeir bought himself/*her/ *wife-the.DAT apartment.ACC in New York fyrir 10 milljónir dollara.

New York for ten million dollars
} 
'Jón Ásgeir bought himself an apartment in New York for ten million dollars.'

(21) Og peir útveguðu honum lóð undir nýja LHÍ-húsið.

and theygot him lot.DAT under new LHÍ-house-the.ACC

'And they got him a lot for the new LHÍ house.'

Per Arne Westerberg ... kjopte seg/ *henne/*kona en

Per Arne Westerberg bought himself/*her/ *wife-the a

hytte for 350000 kroner ...

cottage for 350.000 krones

'Per Arne Westerberg bought himself a cottage for 350,000 krones ...'

(23) Vi skal ikke bare skaffe dem en jobb og et hjem...

we shall not only get them a job and a home

'It is not only our task to get them a job and a home ...'

Such lexical irregularities are problematic for projectionist generative approaches of the type exemplified by Levin and Rappaport Hovav (1995). Their use of lexical rules as ways of explaining syntactic behavior presupposes that the verbs involved form a coherent class defined by specific semantic features, and that "same semantics" implies "same syntax" (cf. Baker's 1988 UTAH: Uniformity of Theta Assignment Hypothesis, whereby identical thematic relations are uniformly represented in syntactic D-structure). In other words, Levin and Rappaport Hovav's approach cannot account for differences in argument realization between pronouns and full NPs of the type shown above. Our examples clearly demonstrate that near-synonymous verbs from the same semantic verb class show unexpected variable argument realization with respect to word class. In contrast, on the present approach where constructions are assumed to exist at different levels of schematicity, ranging from highly abstract schematic constructions to concrete lexically-filled verb-specific constructions with intermediate levels in between, this part-of-speech alternation is coded at the level of verb-specific constructions and is hence non-problematic.

Although the reflexivity constraint may be specific for West Scandinavian, i.e., not found in East Scandinavian or West Germanic (Barðdal 2007: 16-18), there are Norwegian dialects where no such specifications exist with verbs of obtaining and creation. Attested examples like the following are rare to come by, even though they can be found:
Kjopte dem en tallerken hver og et serveringsfat, så kan de bought them one plate each and a platter so can they evnt supplettere [sic] det selv etterhvert.
eventually supply it themselves along
'Bought them one plate each and a platter, and then they can eventually stock up themselves later on.'

It turns out that there are significant dialectal differences in this respect. It seems that the Norwegian dialects spoken in the northern part of Norway allow non-reflexive indirect objects with verbs of obtaining and creation. Sæther (2001: Ch. 5) has carried out an acceptability survey, comparing South- and North-Norwegian dialects, and although the results are more gradient than can be discussed here, it turns out that ten out of ten North Norwegian informants from Kvaløy report that Han bestilte mae en 
billett 'He reserved me a ticket' is fully acceptable, while none of the South Norwegian informants from Asker accept such structures. Also, six out of ten from North Norway fully accept Ho strøyk han fem skjorter 'She ironed him five shirts', four informants are uncertain, whereas all ten South Norwegian informants totally reject such examples. Hence, in the remainder of this article, our discussion and generalizations only hold for Standard Modern Norwegian, which is closest to the dialects spoken in Southern Norway. We now turn to a different subconstruction of the Ditransitive Construction in Norwegian also involving reflexives, i.e., the semantically specific V-REFL-NP Construction.

\subsection{The V-REFL-NP Construction}

The semantically specific V-REFL-NP Construction in Norwegian can be exemplified in the following:

(25)a. ... spiste og tok oss en ol $i$ solen. ate and took ourselves a beer in sun-the '... ate and got us a beer in the sun.'

b. Thomas gikk seg en kveldstur, mens de andre koste Thomas walked himself an evening-walk while the others enjoyed seg med beskyldninger, løgn og svik.

themselves with accusations, lies and betrayals

'Thomas took a late walk while the others enjoyed themselves with accusations, lies and betrayals.'

c. Hadde en slik periode for ikke lenge siden, og folte meg så had a such period for not long ago and felt myself so selvsikker at jegfaktisk greide a finne meg en kjwereste. self-assured that I actually managed to find myself a girlfriend 'I had such a period not long ago, and I felt so self-assured that I actually managed to find me a girlfriend.'

d. ... at det innimellom er digg å bake seg en pris. that it in-between is cool to bake oneself a pinch-of-snuff '... that it is cool once in a while to roll oneself a pinch of snuff.'

e. Han måtte alltid ha seg en stoyt etter endt jobb. he must always have himself a swig after finished work 'He always had to have a swig after work.'

Observe that not all the Norwegian verbs which can only be used with a reflexive indirect object are instantiations of the V-REFL-NP Construction. To show that the VREFL-NP Construction is different from the compositional Ditransitive Construction with a reflexive, we start with an overview of the syntactic properties of the V-REFLNP Construction in Section 5.3, before we discuss its specific or non-compositional semantics in Section 5.4 . 


\subsection{Irregular syntactic behavior}

Traditionally in the literature, not much interest has been taken in Ditransitives of the type discussed in this section, as reflexives have not necessarily been regarded as fullfledged arguments. The ability of a reflexive to be substituted by a full NP has been considered one way of testing argumenthood (cf. Barðdal 2001b: 48). The object of our investigation in this section are reflexives that cannot be substituted by full NPs in Norwegian, like strikke seg en genser 'knit oneself a sweater' and ta seg en øl 'get oneself a beer', although we have no doubts about the argument status of the NPs in the first-mentioned construction, as the semantic contribution of the indirect reflexive object is the same as for other regular ditransitive expressions (see next section). They also behave syntactically in the same way as full NP indirect objects, with the exception of the syntactic behavior that can be directly related to the fact that they are reflexives. The argument status of the reflexive in the V-REFL-NP Construction in the second example, i.e., ta seg en $ø l$ 'get oneself a beer', is of more concern to us here, as its syntactic properties are ambiguous, in part in conformity with the behavior of other indirect objects and in part not. The semantic contribution of the indirect object in the V-REFL-NP Construction cannot be compositionally derived either.

First of all, the V-REFL-NP Construction does not, in all respects, behave according to the general syntactic rules of Norwegian. It can, for instance, neither passivize nor can the reflexive indirect object be topicalized. These restrictions follow directly from the fact that the indirect object is reflexive (cf. Lødrup 2008: 165), evident by the fact that the same pattern is obtained for ordinary verbs of creation and obtaining, not shown here for reasons of space.

There is a syntactic difference, however, found between ordinary verbs of creation and obtaining with a reflexive and our V-REFL-NP Construction, which cannot be attributed to the fact that the indirect object is reflexive. This difference lies in the fact that ordinary reflexive indirect objects can be both topicalized and rightdislocated (when the indirect object is unusually heavy), thereby acquiring an empatic pronoun selv 'self, and turning into a til- 'to' phrase, respectively, see (26). The reflexive of the V-REFL-NP Construction, however, cannot show up as an emphatic til 'to'-phrase when topicalized or right-dislocated, as shown in (27):

(26)a. Hun strikket seg en genser.

she knitted herself a sweater

'She knitted herself a sweater.'

b. Til seg selv strikket hun en genser. Emphatic topic til 'to'-phrase to herself self knitted she a sweater

'To herself did she knit a sweater.'

c. Hun strikket en genser til seg selv

she knitted a sweater to herself self

Heavy til 'to'-phrase

som aldri kunnefå nok varme klaer.

who never could get enough warm clothes

'She knitted a sweater to herself as she could never get enough warm clothes.'

(27)a. Han tok seg en øl.

he took himself a beer

'He got himself a beer.' 
b. *Til seg selv tok han en ol. Emphatic topic til 'to'-phrase to himself self took he a beer

c. *Han tok en ol til seg selv Heavy til 'to'-phrase he took a beer to himself self som aldri sa nei takk til god drikke. who never said no thanks to tasty beverages

The examples in $(27 b-c)$ are possible when the semantics is allative, i.e., when the subject referent 'pulls a beer in his/her general direction', but not with the semantic content intended here, that the subject referent 'got himself a beer'. We thus see that the reflexive of the V-REFL-NP Construction exhibits idiosyncratic behavior in that it fails to participate in the syntactic alternation found for the reflexive in (26b-c).

Observe, moreover, that irrespective of these syntactic idiosyncratic properties, the reflexive indirect object still conforms to general word order rules in Norwegian which specify that the indirect object always precedes the direct object in neutral word order constructions:

(28)a. Hun strikket seg en genser. Neutral word order she knitted herself a sweater 'She knitted herself a sweater.'

b. Han tok seg en $\boldsymbol{e l}$.

he took himself a beer

'He got himself a bear.'

This strict internal order between the two objects is also found when there is an auxiliary in the sentence (29), in questions (30) and in imperatives (31):

(29)a. Hun hadde strikket seg en genser.

Auxiliary insertion

she had knitted herself a sweater

'She had knitted herself a sweater.'

b. Han hadde tatt seg en ol.

he had taken himself a beer

'He had gotten himself a bear.'

(30)a. Strikket hun seg en genser?

knitted she herself a sweater

Questions

'Did she knit herself a sweater?'

b. Tok han seg en ol?

took he himself a beer?

'Did he get himself a beer?'

(31)a. Strikk deg en genser!

knit yourself a sweater

Imperatives

'Knit yourself a sweater!' 


\section{b. Ta deg en $\boldsymbol{\theta l !}$}

take yourself a beer

'Get yourself a beer!'

Note, therefore, that the reflexive element of the V-REFL-NP Construction behaves as an indirect object in Norwegian in that it occupies the same slot in the sentence as other indirect objects, i.e., immediately before the direct object across various sentence patterns, and, as expected, it occurs in the oblique form. These are two of the formal properties of indirect objects.

These facts suggest that the notion of construction, as a form-function correspondence, is needed in order to both explain this abberant behavior of the $\mathrm{V}$ REFL-NP Construction and to formalize it. On such an approach the reflexive argument is not licenced by the verb, but rather by the construction itself. The analysis that the reflexive is an argument of the construction is equivalent to the analysis of fake objects being contributed by constructions, and not by verbs, suggested for instance by Goldberg (1995), Boas (2003) and Iwata (2006).

\subsection{Specific or non-compositional semantics}

Consider now the systematic semantic correspondence found with verbs of obtaining and creation when used transitively and ditransitively:

hekle en $d u k$
crochet a table-cloth

(33)a. bygge et hus build a house

\section{(34)a. kjøpe mat} buy food b. hekle seg en duk crochet oneself a table-cloth

b. bygge seg et hus build oneself a house

b. kjøpe seg mat buy oneself food

In all these examples the contribution of the reflexive indirect object is the same, i.e., it points to the subject referent as the recipient or the beneficiary of the event denoted by the predicate. This is a systematic semantic correspondence found for ordinary Transitive and Ditransitive Constructions, not only with verbs of creation and obtaining, but also with other verb classes, provided that the indirect object can be construed as a reflexive. Hence, the semantic contribution of the reflexive indirect object here is regular, predictable and derivable from the semantics of the parts.

The semantic contribution of the reflexive indirect object of the V-REFL-NP Construction is not as regular as with the other subconstructions of the Ditransitive Construction. Let us start with the verbs which instantiate the V-REFL-NP Construction, from (25a-e) above, and their transitive counterparts:
(35)a. ta en $ø l$
take a beer
b. ta seg en $ø l$ take oneself a beer
(36)a. gå en tur walk a walk
b. gå seg en tur walk oneself a walk


(37)a. finne en kjoreste find a girlfriend

(38)a. bake en snus
roll a snuff
(39)a. *ha en stoyt
have a swig b. finne seg en kjoreste

find oneself a girlfriend

b. bakeseg en snus

roll oneself a snuff

b. ha seg en støyt

have oneself a swig

Observe first that one of the verbs above, $g a$ 'walk' in (36), is not a transitive verb, but an unergative verb, although here used with its content object tur 'walk'. Second, there is no baking involved in bake en snus 'roll a snuff', confirmed by the English use of roll instead of 'bake' for such an event. Third, the verbs finne 'find' in (37) and $h a$ 'have' in (39) are not even agentive predicates. The verb finne is an inchoative verb, although it may entail some degree of involvement also in the ordinary Transitive Construction, as in finne en job 'find a job'. But in the V-REFL-NP Construction with a reflexive, there is quite another dimension added of agentive involvement and desirability of obtaining the object, which cannot be attributed to the semantics of the verb (see below). The verb $h a$, moreover, is a stative verb, although here the meaning of $h a$ is not that of possession, as discussed in Section 4.3 above. It rather means 'get' when used in the Ditransitive Construction in Norwegian. The lexical predicates finne 'find' and $h a$ 'have' do therefore not provide the agentive semantics found in (37b) and (39b). The lexical semantics of the individual items in the complement NPs in (37b) and (39b) cannot be regarded as accountable for the agentive semantics either. The agentivity of these ditransitives can therefore not be compositionally derived, as in the case of the ordinary Ditransitive Construction. This semantic aspect must therefore be assigned non-compositionally, regarded as coming from the construction itself.

Note also that the transitive ha en støyt in the meaning 'have a swig' does not even exist in Norwegian. It is therefore clear that in this case what is often referred to as a "free dative" or a "free beneficiary" (cf. Brøseth 1997: 17-18) has not been added to an otherwise transitive agentive verb, as there is no transitive agentive verb here. Another difference between the so-called free datives and our indirect object is that free datives are not confined to reflexives, but can be ordinary pronouns as well as full NPs. Consider a textbook German example of a "free dative":
Man hat dem Jungen das Buch zerrissen.
one has the boy.DAT the book.ACC torn
'They tore the boy's book.' (Tarvainen 1987: 97)

A problem here is that the category of "free datives" is a waste-paper basket category and there are no formal and semantic criteria that unify the instances discussed in the literature under the heading "free datives". We know, moreover, of no claim in the literature to the effect that "free datives" can only occur as reflexives. In the case of the Norwegian V-REFL-NP Construction, however, only a reflexive indirect object is possible in (39b). Analyzing the reflexive indirect object here as a free dative is therefore not an unproblematic option.

As with the ordinary Ditransitive Construction, the occurrence of a reflexive indirect object with the predicates in (35-39) of course points to the subject referent as being the recipient or the beneficiary of the event denoted. However, this is not all 
that is contributed by the reflexive indirect object. In all cases, the use of the Ditransitive V-REFL-NP Construction entails active execution of the event, an extra effort, on the behalf of and to the benefit of the subject referent, even though the main predicate is stative or inchoative. The object, moreover, must also denote something particularly desirable for the subject referent. Consider the following examples:

(41)a. Jeg fant en dame på gata.

I found a girl on street-the

'I found a girl on the street.'

b. Jeg fant meg en dame på gata.

I found myself a girl on street-the

'I found me a girl on the street.'

Imagine a situation where one is on one's way to the office one morning and sees a half-dead girl lying in the gutter. In such a case can one utter the sentence in (41a) without the reflexive indirect object, I found a girl on the street, but not the example with the ditransitive in (41b), I found me a girl on the street. In contrast, imagine that one, on the way home from the office, meets an unknown woman, starts talking to her, and later develops something romantic with her. In such a case can one utter the sentence in (41b), I found me a girl on the street, as that clearly involves a romantic relationship, and not the sentence in (41a), I found a girl on the street, which has no romantic connotations at all (cf. also the discussion in Sveen 1996: 245-250 on transitive vs. ditransitive usages of Norwegian finne 'find' and $f a ̈$ ' $g$ et').

Consider another example which shows that the Norwegian transitive verb of obtaining, vinne 'win', does not go well with the Ditransitive:

(42)a. Han vant en bil $i$ lotteriet.

he won a car in lottery-the

'He won a car in the lottery.'

b. ??Han vant seg en bil $i$ lotteriet.

he won himself a car in lottery-the

We believe that the reason for the infelicitousness of (42b) is that the Ditransitive VREFL-NP Construction implies that the subject referent is actively involved in bringing about the event, and this is normally not possible when winning in a lottery, which is something beyond one's control or involvement. This analysis is confirmed by the fact that the few ditransitive uses of vinne that we have come across all entail active involvement on the behalf of the subject referent, and none involves lotteries:

(43)a. Som dere kanskje ser tok det ikke lang tid før han vant as you maybe see took it not long time before he won seg en haug med penger.

himself a howe with money

'As you might see, it didn't take long until he had won himself a pile of money.'

b. Og heltinnene er ordentlige handlekraftige damer som gjerne and heroines-the are proper vigorous ladies who usually 
vinner seg en vakker prins til slutt.

win themselves a beautiful prince to end

'And the heroines are proper vigorous women who usually win themselves a beautiful prince in the end.'

In (43a) the subject referent has gone to a casino, which certainly entails both active involvement and an effort in trying to win some money, while in (43b) the 'winning' effect is a consequence of heroic efforts, super efforts in other words.

Given these considerations, we believe that the translation of the ditransitive examples in (35-39) above need to take the extra agentive and desirable effect into account. We thus suggest the following translations:

(44) a. ta seg en $\varnothing l$ 'treat oneself to a beer'

b. gå seg en tur 'treat oneself to a walk'

c. finne seg en dame 'succeed in searching for female company'

d. bake seg en pris 'treat oneself to a pinch of snuff'

e. ha seg en støyt 'treat oneself to a swig'

The semantic contribution of the Ditransitive V-REFL-NP Construction can be characterized by three interconnected points:

- The subject referent is actively involved in bringing about the event expressed by the verb.

- The event is always in the best interest of the subject referent, meaning that this referent is both the instigator of the action and the benefactive (the latter being syntactically expressed by the reflexive indirect object).

- It is a feature of the semantics of this construction that what is denoted by the direct object, or the end result of the event denoted, appears to be something especially desirable to the subject referent.

Beginning with the first point, in (45a) below there was an extra effort by the speaker to find a new girlfriend for himself, and (45b) does not just mean that someone was served food, but rather that they were actively involved in preparing it: ${ }^{3}$

(45)a. Hadde en slik periode for ikke lenge siden, og følte meg så had a such period for not long ago and felt myself so selvsikker at jegfaktisk greide a finne meg en kjareste. self-assured that I actually managed to find myself a girlfriend' 'I had such a period not long ago, and I felt so self-assured that I actually managed to find me a girlfriend.'

b. Etterhvert ble det litt kaldt, så da gikk vi inn igjen after each became it little cold, so then went we in again og fikk oss litt mat.

and got ourselves little food

'After a while it turned a little cold, so we went back inside and got ourselves some food.'

As for the second point, that it always is the subject referent him- or herself who benefits from the event, the examples below are possible only with reflexive indirect 
objects, and substituting them with full referential NPs sounds odd:

(46)a. Kokte meg/ ??gjestene kylling-nudler og kaffe, samt militcercooked myself/ guests-the chicked-noodles and coffee,plus militarykjeks, pølsesnabb og sjokolade. crackers, sausage-end and chocolate 'Cooked me chicken noodles and coffee, with some military crackers, end piece of a sausage and chocolate.'

b. Etterjeg kom fra job hoppa jegi dusjen og mekka after I came fromwork jumped I in shower and made meg/ ??barna pizza. me/ ??children pizza

'After coming home from work, I jumped into the shower and made me some pizza.'

c. Jeg har mekka meg/??familien hjemmekino $i$ kjellern. I have made me/ ??family-the home-cinema in basement-the 'I have made me a home cinema in the basement.'

As for the third characteristic point listed above, that what is denoted by the direct object is especially desirable to the subject referent, this means that using this construction is a way of signaling extra comfort, enjoyment or pleasure. Consider the following attested examples from the World Wide Web, which all accentuate the positive aspect by expressing it directly:

(47)a. Jeg kokte meg mat og kakao mens jeglå inni teltet og I cooked me food and cocoa while I lay inside tent and jeg storkoste meg!

I really-enjoyed myself

'I made me food and cocoa, while laying inside the tent and I really enjoyed it!'

b. Vi traska rundt og såg påfolk, satteoss ned på we stamped around and looked on people, sat us down on en uterestaurant og tok oss en ol. Nyte livet! an out-restaurant and took us a beer enjoy life 'We stamped around watching people, sat down at an outdoor restaurant and got us a beer. Oh, to enjoy life!'

c. Jeg som ikke hadde spist den dagen mekka meg brodskiver I who not had eaten that day made me bread-slices med halve kjottboller oppå. Det var faen meg moed godt. with half meatballs on-top. It was devil me really good' 'I, who had not eaten anything that day, made me some bread with half meatballs on top. It was damn me really good.'

d. Nå skal jegut påkjøkkenet og miksemegen HERRRLIG now shall I out on kitchen-the and mix me a DEEELICIOUS proteinsmoothie etter beste Tessa-oppskrift. proteinsmoothie after best Tessa-recipe 
'Now I'm going out in the kitchen to mix me a really DEEELICIOUS protein smoothie, following Tessa's best recipe.'

e. Man kan tilbringe en avslappende dag på stranden $i$ Albir og ta one can spend a relaxing day on beach-the in Albir and take

seg noen deilige bad. Hvis man har eventyret $i$ seg oneself some delightful baths if one has adventure in onself

kan man ta seg noen fine turer innover...

can one take oneself some nice trips inland

'One can relax for a day on the beach in Albir and take some delightful baths.

If one is the adventurous type, it's possible to do some nice trips inland ...'

f. Stod opp laget frokost og niste til ham og kokte meg

stood up made breakfast and lunch-box to him and boiled me

en kopp te og leste avisen.

a cup tea and read paper-the

'Got up, prepared breakfast and a lunch box for him and made me a

cup of tea and read the paper.'

Consider the last example, (47f). It is worth noting that the subject referent makes breakfast and a lunch packet for another person, using the V-NP-PP-construction with a prepositional object, but makes "a nice cup of tea" for herself with the pleasurable V-REFL-NP Construction. That is, in spite of the fact that this speaker has primed herself with the prepositional pattern, she still shifts over to the V-REFL-NP Construction when describing the part of the event that was carried out for herself. She could of course have expressed the last part with a to-phrase (og kokte en kopp te til meg selv), but this would not have accentuated the pleasure and the enjoyment, and would thus not have been an instance of our V-REFL-NP Construction.

The more censorious reader could now ask how we can be sure that the positive meaning effect that we have identified here is built into the constructional meaning, and not simply a derivative of the meaning of the lexical items instantiating the construction in all these examples. After all, all the examples above contain objects denoting something enjoyable, according to general social standards. In order to address this issue, consider the following examples which contrast 'girlfriend' and 'university':

(48)a. Han fant seg en kjaereste.

he found himself a girlfriend

'He found himself a girlfriend.'

b. Han fant seg et universitet å søke seg til. he found himself a university to apply oneself to 'He found himself a university to apply to.'

Clearly, getting a girlfriend must be regarded as a positive thing in life, while finding a university to apply to would appear as more neutral, neither particularly positive nor particularly negative, at least according to our judgment of general social standards. However, in our view, there is no difference between the two examples in (48) with regard to the extra efforts of the instigator, i.e., the subject referent, nor with regard to the perceived desirability of "obtaining the object". This meaning component of the 
V-REFL-NP Construction, that the object is particularly desirable for the subject referent, is also found in examples like (48b), despite the fact that the reference of the object in (48b) appears to be more neutral with regard to general consensus on what is particularly enjoyable in life and what not. Or put differently, the sentence in (48b) would be preferred over its corresponding transitive counterpart by a speaker who views applying to a university as a particularly positive event in life, while the corresponding transitive would be preferred by a speaker who does not share the view that such an event is positively laden. To conclude, the effect of extra enjoyment or pleasure is not generally derivable from the lexical meaning of the NP in the direct object slot, or from our real-world attitudes towards the content of that NP, but must be coming from the construction itself.

Norwegian has a manner of expression which is formally identical to the VREFL-NP Construction, but semantically the opposite:

\author{
(49)a. Det ender med at begge fär seg en blåveis og \\ it ends with that both get themselves a black-eye and \\ Frank ender på glattcelle. \\ Frank ends on security-cell \\ 'In the end, both get a black eye and Frank ends up in a security cell.'
}

\title{
b. Mikkel Isak hadde fätt seg en trokk $i$ skallen. \\ Mikkel Isak had gotten himself a kick in head-the \\ 'Mikkel Isak got his head kicked in.'
}

Those examples are of course also instances of the Norwegian Ditransitive Construction with a reflexive. We maintain, however, that these examples are not instances of our V-REFL-NP Construction, but rather of another subconstruction of the Ditransitive Construction in Norwegian. Observe that examples of this type only occur with the verb $f \stackrel{\circ}{ }$ ' $\mathrm{get}$ ' and a handful of nouns in the object slot, which suggests a certain degree of lexicalization. Indeed there may be a connection between the use of this pattern and the V-REFL-NP Construction, namely that they both add some kind of emphasis or amplification of the event's impact. To be sure, there is no extra effort of the subject referent involved in such cases, but there is a sense of the agent getting $\mathrm{him} /$ herself into trouble, and this is relevantly similar to the agentivity effect found in more prototypical V-REFL-NP cases.

The question arises as to whether the extra agentivity effect can be derived from the grammatical meaning of the reflexive pronoun seg or from the rules combining the lexical items together. These two, i.e., the meaning of the lexical items and the rules combining the lexical items together are the two elements of the Principle of Compositionality (Frege 1964). A problem for the former analysis is that an extra agentivity effect is not consistently found in all constructions with a reflexive. In examples like "He saw himself in the mirror", no extra agentivity is noticeable. Therefore, deriving the extra agentivity effect from the meaning of seg can only be done on the assumption that the grammatical meaning of seg is vague and that the relevant meaning of seg, in this case the extra agentivity effect, is somehow triggered either by the meaning of the surrounding lexical items or by the combination of seg and the surrounding lexical items. This analysis is in principle the same as the second possible analysis mentioned above, namely that the extra agentivity effect is somehow derivable from the "rules" combining the lexical items together. Observe, however, that such an analysis would only be a notational variant of our constructional analysis, 
as it presupposes that this particular meaning of seg is either selected by the combination of seg and the other lexical items of the sentence or that it is built into a "rule" combining the lexical items, a rule which would then be specific for the ditransitive pattern at issue here.

However, assuming a specific rule for this sentence pattern entails that the semantic nuance of extra agentivity is simply not derived compositionally anymore, as evident from the use of the term specific here. If this were not a specific rule, only valid for this construction, it should be found across sentence patterns, which it is not. Moreover, such a specific rule would not be able to capture the difference between the general compositional Ditransitive Construction with a reflexive and the V-REFL-NP Construction in Norwegian, as this rule should apply equally to both of them. The extra agentive effect, however, is not found with the general compositional Ditransitive Construction, but only with the specific non-compositional one, i.e., the V-REFL-NP Construction. In order to capture the difference between the two, this specific rule would have to be modified to only cover the V-REFL-NP Construction, presumably involving a predefined set of lexical verbs. As already stated above, such an analysis would only be a notational variant of our constructional analysis, as it would target a specific predefined argument structure construction, with a specific predefined set of predicates. In essence it would therefore only target a subset of the instantiations of the Norwegian Ditransitive Construction, or more precisely, a subset of those occurring with a reflexive indirect object.

In contrast, we have chosen to advocate a constructional analysis of the VREFL-NP Ditransitive Construction in Norwegian, as we actively acknowledge that the reflexive seg does not exist outside of constructions where seg is combined with other lexical items. That is, reflexive seg is not used by itself in isolation. Therefore, the meaning of seg does not exist outside of larger constructions. We have chosen to acknowledge this fact and thus we lay the burden of the relevant semantic nuance on the construction itself, i.e., the form-function correspondences, which we regard as the basic primitive of language.

Our main concern in this section has been to define the semantics of the VREFL-NP Construction. As for formal traits, in addition to the requirement that the indirect object must be reflexive, examples $(27 b-c)$ in Section 5.3 above show that the strict constituent order $[\mathrm{V}+$ reflexive $+\mathrm{NP}]$ is necessary to express the particular semantics involved. This is what distinguishes our V-REFL-NP Construction formally from the ordinary compositional reflexive Ditransitive Construction with verbs like kjøpe 'buy' or strikke 'knit', which allow a paraphrase with til 'to' in topicalizations and right dislocations, in opposition to ta seg en øl 'treat oneself to a beer'. As our discussion below example (47f) shows, a few of the verbs occurring in the V-REFLNP Construction allow this paraphrase, but when paraphrased, the semantic nuance associated with the V-REFL-NP Construction disappears. This stands in a stark contrast to the verbs occurring in the general compositional Ditransitive Construction, as they do not show this change in semantic.

A final question to address is where the extra semantic component of the $\mathrm{V}$ REFL-NP Construction comes from. The fact that the indirect object of the Ditransitive V-REFL-NP Construction is reflexive may have had certain implications relevant for the origin of the non-compositional semantics. That is, since the instigator and the beneficiary of the event are one and the same person, this may result in more uses where a desirable object fills the object slot. In other words, since the instigator is carrying out an event in his or her own favor, it would not come as a surprise if there are more usages where the object slot is filled with an NP denoting something 
desirable for the instigator. This is therefore a pragmatic implicature. That is, this conventionalization may have arisen because of pragmatic reasons. The seed giving rise to the additional meaning component of the V-REFL-NP Construction lies in the fact that the instigator and the beneficiary are the same person. As people are more likely to actively pursue things and results that are desirable to them, than to pursue things that they do not find desirable, this meaning has come to be associated with the construction through repeated use. This may also explain why so many of the predicates instantiating the V-REFL-NP Construction are verbs of obtaining and creation, as many of the other predicates do not denote events that target the subject referent him- or herself. Given these presuppositions, the emergence of the V-REFLNP Construction in Norwegian is due to a pragmatic extension of the ordinary Ditransitive Construction.

If our analysis of the emergence of the extra semantic component of the VREFL-NP Construction in Norwegian has a natural basis in the fact that the indirect object is reflexive, as people may be more prone to actively engage themselves in acquiring something enjoyable for themselves, this predicts that the same pragmatically-motivated extension should be found in more languages. In fact, this prediction seems to be borne out. For instance, 'to find oneself a girlfriend' is considerably more agentive than 'to find a girlfriend, in both Icelandic and English, at least. The same is true for 'getting oneself a beer' and 'getting a beer'. It has been suggested to us that similar semantic effects may be found with the reflexive Ditransitive in the Polish language (Piotr Garbacz, p.c). An anonymous reviewer has also pointed out to us that this construction has parallels in Romance, like in the following example from French:

$$
\begin{aligned}
& \text { Je me mange une pizza. } \\
& \text { I me eat a pizza } \\
& \text { 'I treat myself to a pizza.' }
\end{aligned}
$$

Consider also the following English example which, as opposed to the ordinary transitive, highlights the event, the extra effort on the behalf of the subject referent, and the enjoyable object/end state/consequences:

\section{Well, Folks. Barack Obama Has Won Himself The State Of Ohio.}

(headline in the Atlantic)

The following examples from Icelandic all entail some sort of an extra involvement on the behalf of the subject referent, as compared to their transitive counterparts:

(52)a. Her á sér fegra föðurland?

who ownes him/herself.DAT more-beautiful fatherland.ACC

'Who has a more beautiful fatherland?'

(from the Icelandic nationalistic song "Hver á sér fegra föðurland?”)

b. Martin Luther King átti sér draum.

Martin Luther King owned himself.DAT dream.ACC

'Martin Luther King had himself a dream/mission.'

More research, particularly of typological nature, is needed to establish whether this kind of a pragmatically-motivated extension has a natural basis in people's inclination 
to actively pursue positive things for themselves, as opposed to pursuing negative things, and whether this inclination is linguistically lodged in the world's languages, or whether it may be restricted to Indo-European.

\subsection{Interim summary}

In this section we have compared the syntax and semantics of the ordinary Norwegian Ditransitive Construction with a reflexive indirect object and the corresponding VREFL-NP Construction. We have shown that certain aspects of the syntactic behavior of the V-REFL-NP Construction are not derivable from any general syntactic or grammatical rules in Norwegian, nor are they derivable from any specific syntactic or grammatical rules targeting reflexives. More specifically, indirect reflexive objects must occur with an emphatic pronoun, materialized as a 'to'-phrase, when topicalized or subject to heavy right-dislocation. This behavior is generally not found for the reflexive indirect object of the V-REFL-NP Construction. In contrast, other aspects of the syntactic behavior of the reflexive indirect object of the V-REFL-NP Construction, such as word order properties, are quite regular.

Regarding the semantics of the construction, the regular systematic semantic correspondence found for transitive and ditransitive uses of verbs of obtaining and creation is not found for transitive and ditransitive expressions instantiating the $\mathrm{V}$ REFL-NP Construction. In fact, certain verbs instantiating this construction do not even have a transitive counterpart, and others have a different meaning when used transitively. There is, moreover, an additional semantic nuance, found for the VREFL-NP Construction, of a) high degree of agentivity, or extra effort or involvement, on the behalf of the subject referent, b) to the benefit of the subject referent, c) resulting in a particularly pleasurable or enjoyable end result. Only the point under b) can be directly derived from the syntax or the semantics of the construction, namely from the fact that there is an indirect object which is reflexive. The point under c) is a pragmatically-motivated extension of point $b$ ), not derivable from the strict semantics of the individual parts. The point under a) cannot be compositionally derived from the semantics of the parts either. 


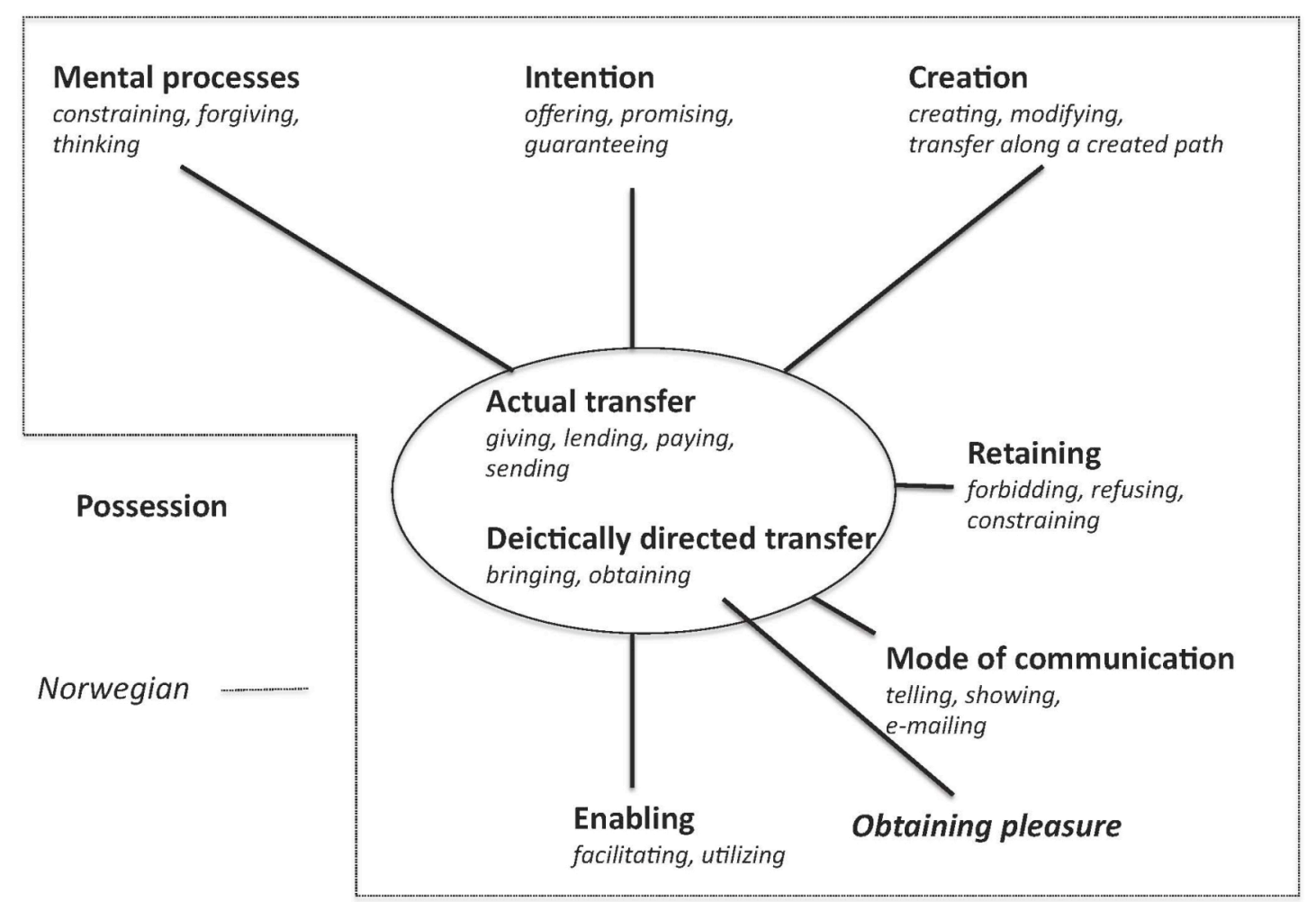

Figure 6. A revised semantic map of the Norwegian Ditransitive Construction, including the $V$-REFL-NP Construction

It is therefore clear that in addition to the general Ditransitive Construction in Norwegian, where the semantics of the whole can be compositionally derived from the semantics of the parts, there also exists a specific semantically non-compositional Ditransitive Construction, the V-REFL-NP Construction, which semantics cannot be compositionally derived from the semantics of the parts. This construction has come into existence through a pragmatic extension of the general subconstruction of obtaining, and we therefore place it in our semantic map in Figure 6, as an extension of the Ditransitive Subconstruction of obtaining. We also show, in Figure 7, the location of the specific non-compositional V-REFL-NP Construction in the Norwegian ditransitive lexicality-schematicity hierarchy. Our analysis of the origin of this V-REFL-NP Construction, as a pragmatically-motivated extension derived from the fact that the instigator and the beneficiary are the same person, makes certain predictions about the existence of such a subconstruction in other languages. That is, if pragmatically-motivated extensions of this kind naturally arise because of context and repeated use, one would expect to find them in more languages. This prediction seems to be borne out by data from Icelandic, English, French and Polish. 


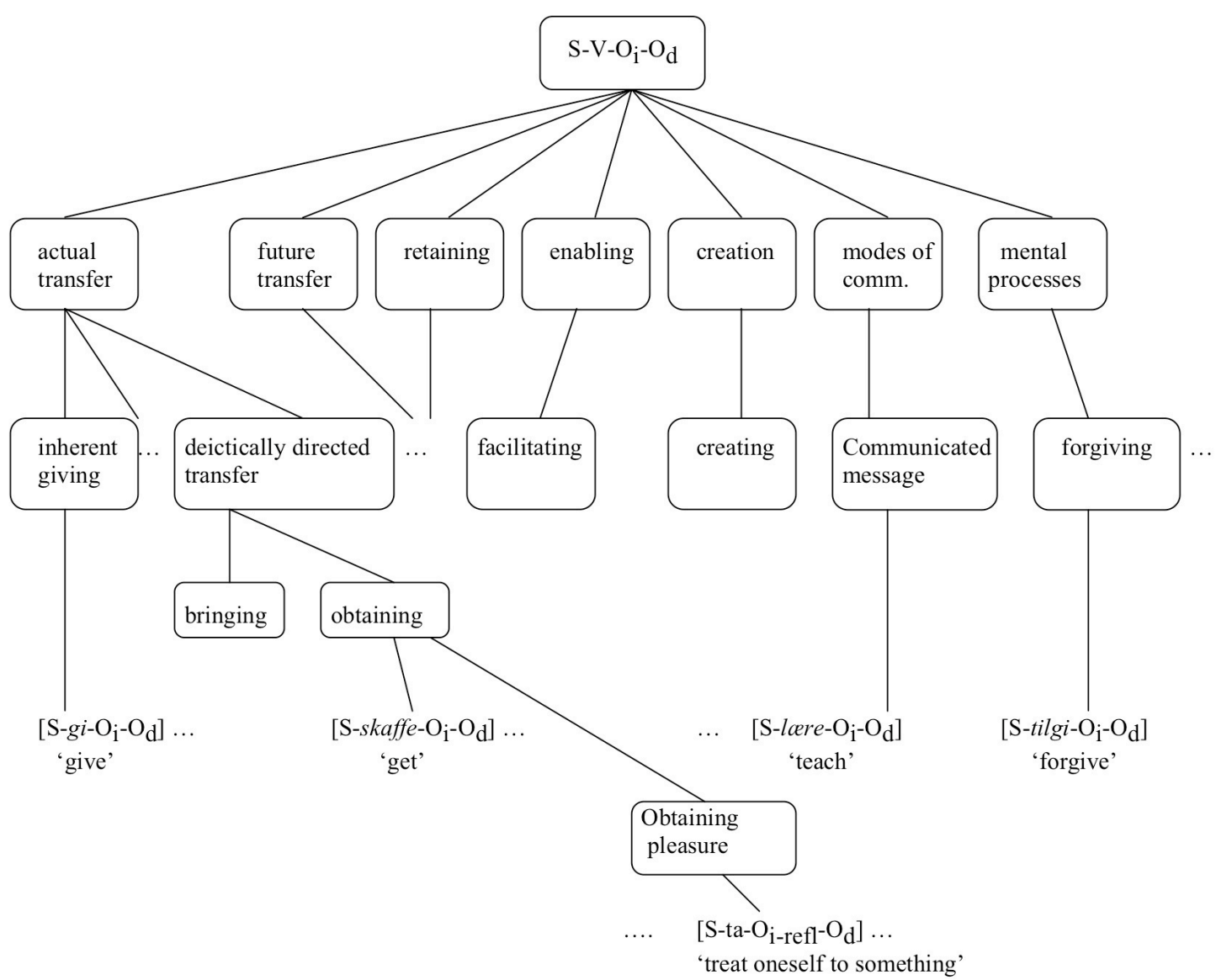

Figure 7. A revised lexicality-schematiciy hierarchy of the Norwegian Ditransitive Construction, including the V-REFL-NP Construction

\section{Summary}

Earlier construction-based work on the lexical and semantic scope of the Ditransitive Construction in the Germanic languages has first and foremost been based on English. A recent article by Barðdal (2007), providing data mostly from Icelandic, has shown that the inventory of verbs instantiating the Ditransitive Construction is semantically much richer in Icelandic than in Standard English, including not only verbs of actual, intended, retained and metaphorical transfer, but also verbs of transfer along a path, verbs of possession, utilizing, enabling, hindrance, constraining and verbs denoting mental activities. In other words, the Ditransitive Construction is far from being confined to the concept of transfer as indicated by earlier construction-based analyses of the Ditransitive Construction, which are first and foremost based on Standard English. In order to investigate whether the semantic scope of the construction has expanded in Icelandic or been reduced in, for instance, English, we have carried out a study of the lexical and semantic scope of the Ditransitive Construction in the WestScandinavian languages, i.e., Icelandic, Faroese and Norwegian, and their predecessor, Old Norse. Our findings show that the semantic scope of the Ditransitive Construction has remained remarkably stable during the last thousand years, suggesting a wider semantic scope of the construction in Proto-Germanic than in, for instance, Standard Modern English, illustrating the danger of arriving at a lopsided analysis when dialectal data are ignored.

We have, moreover, suggested an analysis of the Ditransitive Construction in 
terms of eight different higher-level semantic categories, i.e., ACTUAL TRANSFER, INTENTION, CREATION, MODE OF COMMUNICATION, ENABLING, RETAINING, MENTAL PROCESSES and POSSESSION, and hence a network of meanings associated with the Ditransitive Construction in West-Scandinavian. We suggest a semantic map for the Ditransitive Construction, which turns out to be valid not only for the initial Modern Icelandic data, but also for the four low type frequency case constructions in Old Norse. Each case construction occupies adjacent regions in semantic space, hence complying with Croft's Semantic Map Connectivity Hypothesis.

We have also suggested an analysis of the structure of the Ditransitive Construction in West-Scandinavian in terms of a lexicality-schematicity hierarchy. The most schematic Ditransitive Construction, V-IO-DO, is located at the top of the hierarchy, the higher-level semantic categories occupy the level below that, the verbclass-specific constructions are located one level below that, and at the bottom of the hierarchy we find verb-specific constructions where lexical idiosyncracies are encoded. Lexicality-schematicity hierarchies of this type make it possible to capture higher-level generalizations, while preserving verb-specific idiosyncratic behavior at the same time. Lexicality-schematicity hierarchies are structured inventories of lexicon-grammar interactions, and as such they are ideal for research within lexical typology, which of course forms the basis for comparative constructional work within the area of argument structure constructions.

Finally, we have investigated a specific subconstruction of the Ditransitive Construction in Norwegian, the V-REFL-NP Construction, and shown that certain aspects of both its syntax and its semantics are irregular. The reflexive indirect object of the V-REFL-NP Construction cannot occur with an emphatic pronoun 'self' in a 'to'-phrase when subject to topicalization or heavy right-dislocation, as opposed to full NP and reflexive objects of the ordinary compositional Ditransitive Construction. Certain semantic nuances, such as a higher degree of agentivity or extra effort on behalf of the subject referent, and a particularly enjoyable end result, cannot be derived from the semantics of the parts. Hence, we have suggested a pragmaticallymotivated extension, based on the fact that the subject and the indirect object, the instigator and the beneficiary, are the same person, and obtaining something positive for oneself may be more desirable than obtaining something negative. We have also discussed possible counterexamples with the verb $f a$ ' 'get' with a few well-selected nouns in the object slot all denoting negative physical impact, and argued that it constitutes a lexicalized subconstruction of its own, with no bearing upon our analysis of the V-REFL-NP Construction in Norwegian.

Our analysis of the V-REFL-NP Construction may be applicable to subconstructions of the Ditransitive Construction in other languages, like English, Icelandic, French or Polish, as some of our examples above have indicated. This needs to be investigated for each of these languages. If true, however, the notion of a construction as a form-function or form-meaning correspondence is needed to account for the non-compositional semantics of this subconstruction in more languages than only Norwegian. This may furthermore suggest that there is a natural basis for the kind of pragmatically-motivated extensions that we have identified here.

\section{References}

Baker, Mark C. 1988. Incorporation: A theory of grammatical function changing. Chicago: University of Chicago Press. 
Barðdal, Jóhanna. 2001a. The perplexity of Dat-Nom verbs in Icelandic. Nordic Journal of Linguistics 24. 47-70.

Barðdal, Jóhanna. 2001b. Case in Icelandic - A synchronic, diachronic and comparative approach (Lundastudier i Nordisk språkvetenskap A 57). Lund: Department of Scandinavian Languages.

Barðdal, Jóhanna. 2004. The semantics of the impersonal construction in Icelandic, German and Faroese: Beyond thematic roles. In Werner Abraham (ed.), Topics of Germanic typology, 105-137. Berlin: Akademie Verlag.

Barðdal, Jóhanna. 2006a. Construction-specific properties of syntactic subjects in Icelandic and German. Cognitive Linguistics 17(1). 39-106.

Barðdal, Jóhanna. 2006b. Predicting the productivity of argument structure constructions. To appear in Berkeley Linguistics Society 32.

Barðdal, Jóhanna. 2007. The semantic and lexical range of the ditransitive construction in the history of (North) Germanic. Functions of Language 14(1). 930 .

Barðdal, Jóhanna. 2008. Productivity: Evidence from case and argument structure in Icelandic. Amsterdam: John Benjamins.

Barðdal, Jóhanna. 2009. The development of case in Germanic. In Jóhanna Barðdal \& Shobhana L. Chelliah (eds.), The role of semantic, pragmatic and discourse factors in the development of case, 123-159. Amsterdam: John Benjamins.

Barðdal, Jóhanna. 2010a. The rise of dative substitution in 19th century Icelandic. To appear in Lingua, a special thematic volume on Case Variation, ed. by Klaus von Heusinger \& Helen de Hoop.

Barðdal, Jóhanna. 2010b. Lexical vs. structural case: A false dichotomy. To appear in Morphology, a special thematic volume on Empirical Approaches to Morphological Case, ed. by Cathryn Donohue \& Jóhanna Barðdal.

Barðdal, Jóhanna \& Thórhallur Eythórsson. 2010. Reconstructing syntax: Construction grammar and the comparative method. To appear in Hans C. Boas \& Ivan A. Sag (eds.), Sign-based construction grammar. Stanford: CSLI Publications.

Barðdal, Jóhanna \& Valéria Molnár. 2003. The passive in Icelandic - Compared to Mainland Scandinavian. In Jorunn Hetland \& Valéria Molnár (eds.), Structures of focus and grammatical relations, 231-260. Tübingen: Max Niemeyer Verlag.

Bárðar saga Snæfellsáss. 1987. In Bragi Halldórsson, Jón Torfason, Sverrir Tómasson \& Örnólfur Thorsson (eds.), Íslendingasögur og pcettir I-III, 46-74. Reykjavík: Svart á hvítu.

Bergen, Benjamin K. \& Madelaine C. Plauché. 2001. Voilà voilà: Extensions of deictic constructions in French. In Alan Cienki, Barbara Luka \& Micheal Smith (eds.), Conceptual and discourse factors in linguistic structure, 45-61. Stanford: CSLI Publications.

Bjarnar saga Hítdælakappa. 1987. In Bragi Halldórsson, Jón Torfason, Sverrir Tómasson \& Örnólfur Thorsson (eds.), Íslendingasögur og pattir I-III, 75-123. Reykjavík: Svart á hvítu.

Boas, Hans C. 2003. A constructional approach to resultatives. Stanford: CSLI Publications.

Bresnan, Joan \& Tatiana Nikitina. 2003. On the gradience of the dative alternation. Ms, Stanford University. http://www.stanford.edu/\%7Ebresnan/new-dative.pdf.

Brøseth, Heidi. 1997. Dobbelt objekt og tilgrensende konstruksjoner i moderne norsk. [Double object and adjacent constructions in Modern Norwegian]. Trondheim: NTNU MA thesis. 
Colleman, Timothy. 2002. De benefactieve dubbelobject-constructie in het 19deeeuws Nederlands [The benefactive double object construction in 19th-century Dutch]. In Roland Willemyns (ed.), De taal in Vlaanderen in de 19de eeuw: Historisch-sociolingü̈stische onderzoekingen, 509-528. Gent: Koninklijke Academie voor Nederlandse Taal- en Letterkunde.

Colleman, Timothy \& Bernard De Clerck 2008. Accounting for Ditransitive Constructions with envy and forgive. Functions of Language 15. 187-215.

Croft, William. 1998. Event structure in argument linking. In The projection of arguments: Lexical and compositional factors, Miriam Butt \& Wilhelm Geuder (eds.), 21-63. Stanford: CSLI Publications.

Croft, William. 2001. Radical construction grammar. Oxford: Oxford University Press.

Croft, William. 2003. Lexical rules vs. constructions: A false dichotomy. In Hubert Cuyckens, Thomas Berg, René Dirven \& Klaus-Uwe Panther (eds.), Motivation in language: Studies in honour of Günter Radden, 49-68. Amsterdam: John Benjamins.

Croft, William, Jóhanna Barðdal, Willem Hollmann, Maike Nielsen, Violeta Sotirova \& Chiaki Taoka. 2001. Discriminating verb meanings: The case of transfer verbs. Paper presented at the LAGB Autumn Meeting, Reading, 4-6 September.

Croft, William \& Alan Cruse. 2004. Cognitive linguistics. Cambridge: Cambridge University Press.

Culicover, Peter W. 2008. The rise and fall of constructions and the history of English Do-support. Journal of Germanic Linguistics 20(1). 1-52.

Faarlund, Jan Terje, Svein Lie \& Kjell Ivar Vannebo. 1997. Norsk referansegrammatikk [Norwegian reference grammar]. Oslo: Universitetsforlaget.

Falk, Cecilia. 1990. On double object constructions. Working Papers in Scandinavian Syntax 46. 53-100.

Fillmore, Charles J., Paul Kay \& Mary Kay O’Connor. 1988. Regularity and idiomaticity in grammatical constructions: The case of let alone. Language 64. 501-538.

Flóamanna saga. 1987. In Bragi Halldórsson, Jón Torfason, Sverrir Tómasson \& Örnólfur Thorsson (eds.), Íslendingasögur og paettir I-III, 728-774. Reykjavík: Svart á hvítu.

Føroyskt TextaSavn [Faroese text collection]. http://spraakbanken.gu.se.

Frege, Gottlob. 1964. Begriffschrift und andere Aufsätze. Hildesheim: Georg Olms Verlagsbuchhandlung.

Fritzner, Johan. 1886-1896. Ordbog over det gamle norske Sprog [Dictionary of the Old Norwegian language]. Kristiania: Den norske Forlagsforening.

Gibbs, Raymond W. Jr. 1995. Idiomaticity and human cognition. In Martin Everaert, Erik-Jan van der Linden, Andre Schenk \& Rob Schreuder (eds.), Idioms: Structural and psychological perspectives, 97-116. Hillsdale, NJ: Erlbaum.

Goldberg, Adele E. 1995. Constructions: A construction grammar approach to argument structure. Chicago: University of Chicago Press.

Goldberg, Adele E. 2002. Surface generalizations: An alternative to alternations. Cognitive Linguistics 13. 327-356.

Goldberg, Adele E. 2006. Constructions at work: The nature of generalization in language. Oxford: Oxford University Press.

Goldberg, Adele E. \& Ray S. Jackendoff. 2004. The English resultative as a family of constructions. Language 80. 532-568.

Hale, Ken \& Samuel Jay Keyser. 1987. A view from the middle. Lexicon Project 
Working Papers 10. 1-36.

Hall, Barbara C. 1965. Subject and object in Modern English. Cambridge, Mass: MIT dissertation.

Haspelmath, Martin. 2003. The geometry of grammatical meaning: Semantic maps and cross-linguistic comparison. In Michael Tomasello (ed.), The new psychology of language, Vol. 2, 211-242. Mahwah, NJ: Lawrence Erlbaum.

Holmberg, Anders \& Christer Platzack. 1995. The role of inflection in Scandinavian syntax. New York: Oxford University Press.

Israel, Michael. 1996. The way constructions grow. In Adele Goldberg (ed.), Conceptual structure, discourse and language, 217-230. Stanford: CSLI Publications.

Iwata, Seizi. 2006. Argument resultatives and adjunct resultatives in a lexical constructional account: The case of resultatives with adjectival result phrases. Language Sciences 28(5). 449-496.

Iwata, Seizi. 2008. Locative alternation: A lexical-constructional approach. Amsterdam: John Benjamins.

Jackendoff, Ray. 1997. Twistin' the night away. Language 73. 534-559.

Jónsson, Jóhannes G. 2000. Case and double objects in Icelandic. Leeds Working Papers in Linguistics 8. 1-94.

Jónsson, Jóhannes G. 2009. Verb classes and dative objects in Insular Scandinavian. In Jóhanna Barðdal \& Shobhana L. Chelliah (eds.), The role of semantic, pragmatic and discourse factors in the development of case, 203-224. Amsterdam: John Benjamins.

Koptjevskaja-Tamm, Maria. 2008. Approaching lexical typology. In Martine Vanhove (ed.), From polysemy to semantic change: Towards a typology of lexical semantic associations, 3-52. Amsterdam: John Benjamins.

Kristoffersen, Kristian E. 1998. Forholdet mellom tematiske roller og syntaktiske funksjoner i norrønt, jamført med tysk og islandsk [The relation between thematic roles and syntactic relations in Old Norse, compared to German and Icelandic]. Arkiv för nordisk filologi, 113. 97-149.

Levin, Beth. 1993. English verb classes and alternations: A preliminary investigation. Chicago: University of Chicago Press.

Levin, Beth \& Malka Rappaport Hovav. 1995. Unaccusativity: At the syntax-lexical semantics interface. Cambridge, Mass: MIT Press.

Lødrup, Helge. 2008. Raising to object in Norwegian and the derived object constraint. Studia Linguistica 62(2). 155-181.

Marantz, Alec. 1993. Implications of asymmetries in double object constructions. In Sam Mchombo (ed.), Theoretical aspects of Bantu grammar, 113-150. Stanford: CSLI Publications.

Malchukov, Andrej, Martin Haspelmath \& Bernard Comrie. 2007. Ditransitive Constructions: A typological overview. Ms. Max Planck Institute, Leipzig.

Maling, Joan. 2002. Pað rignir págufalli á Íslandi [It's raining dative in Iceland]: Verbs with dative objects in Icelandic. Íslenskt mál 24. 31-105 [Also published in a slightly altered English version in Working Papers in Scandinavian Syntax 70. $1-60,2002]$.

Malmsten, Solveig. 2001. Dativbruket i färöiskan över 60 år [The use of dative in Faroese during 60 years]. Uppsala: Uppsala University Ms.

Norsk talespråkskorpus - Oslodelen [Oslo corpus of Spoken Norwegian]. The Text Laboratory, Dept. of Linguistics and Scandinavian Studies, University of Oslo. http://www.tekstlab.uio.no/nota/oslo/index.html. 
Nunberg, Geoffrey, Ivan A. Sag \& Thomas Wasow. 1994. Idioms. Language 70. 491-538.

Norsk talespråkskorpus - Oslodelen. [Oslo Corpus of Spoken Norwegian.]. http://www.tekstlab.uio.no/nota/oslo/index.html

Ottósson, Kjartan G. 1991. Icelandic double objects as small clauses. Working Papers in Scandinavian Syntax 48. 77-97.

Pinker, Steven. 1989. Learnability and cognition: The acquisition of argument structure. Cambridge, Mass: MIT Press.

Rappaport Hovav, Malka \& Beth Levin. 2001. An event structure account of English resultatives. Language 77. 766-797.

Reinhammar, Maj. 1973. Om dativ i svenska och norska dialekter [About the dative in Swedish and Norwegian dialects] (Acta Academiae Regiae Gustavi Adolphi 53). Uppsala: Almqvist and Wiksell.

Sveen, Andreas. 1996. Norwegian impersonal actives and the unaccusative hypothesis. Oslo: University of Oslo dissertation.

Sæther, Kari-Anne. 2001. Dialektforskjeller $i$ realiseringen av indirekte objekt [Dialectal differences in the realization of the indirect object]. Tromsø: University of Tromsø MA thesis.

Tarvainen, Kalevi. 1987. Semantic cases in the framework of Dependency Theory. In René Dirven \& Günter Radden (eds.), Concepts of case, 75-102. Tübingen: Narr.

Thráinsson, Höskuldur, Hjalmar P. Petersen, Jógvan í Lon Jacobsen \& Zakaris Svabo Hansen. 2004. Faroese: An overview and reference grammar. Tórshavn: Føroya Fróðskaparfélag.

Tomasello, Michael. 1998. Cognitive linguistics. In William Bechtel \& George Graham (eds.), A companion to cognitive science, 477-487. Oxford: Blackwell.

Toft, Ellen Hellebostad. 2009. Adnominal and adverbal genitive constructions in Old Norse: A cognitive construction grammar account. Oslo: University of Oslo dissertation.

Webelhuth, Gert \& Clare J. Dannenberg. 2006. Southern American English personal datives: The theoretical signficance of dialectal variation. American speech 81 . 31-55.

Yip, Moira, Joan Maling \& Ray Jackendoff. 1987. Case in tiers. Language 63. 217250.

Zaenen, Annie, Joan Maling \& Höskuldur Thráinsson. 1985. Case and grammatical functions: The Icelandic passive. Natural Language and Linguistic Theory 3. 441483.

Pormóðar páttur (eftir Flateyjarbók). 1987. In Bragi Halldórsson, Jón Torfason, Sverrir Tómasson \& Örnólfur Thorsson (eds.), Íslendingasögur og pattir I-III, 2275-2282. Reykjavík: Svart á hvítu.

\footnotetext{
${ }^{1}$ We have presented parts of this work at Semantik i fokus in Lund (2006), Kognitivt sommarseminar in Oslo (2007), ICLC-10 in Krakow (2007), MONS 12 in Stavanger (2007), the Ph.D. Course: "Expanding Construction Grammar and Frame Semantics" in Bergen (2008) and at the Friday Linguistics Seminar in Bergen (2009). We thank the audiences there for comments and discussions. We are also indebted to Christian-Emil Ore at the Digital Documentation Unit, University of Oslo, for making Fritzner's Old Norse dictionary (1886-1896) electronically available to us, to Guro Fløgstad for help with compiling the relevant data from the Oslo Corpus of Spoken Norwegian, to Hjalmar Petersen and Jógvan í Lon Jacobsen for help with the Faroese data, to Tore Nesset for drawing our attention to the facts of North Norwegian dialects, and to Eystein Dahl, Tonya Kim Dewey, Bridget Drinka, Thórhallur Eythórsson, Piotr Garbacz, Sandra Halverson, Torodd Kinn, Thomas Smitherman, and Kendra Willson for discussions and/or help with the data. Finally, we thank Helge Lødrup and two reviewers of Linguistics, Timothy Colleman and an anonymous one, for comments on the entire
} 
manuscript. The usual disclaimers apply. The names of the authors are listed in alphabetical order.

${ }^{2}$ All examples are attested examples taken from the World Wide Web, unless otherwise specified in the text or made clear from the context.

3 In their discussion of the Southern American English double object construction, Webelhuth and Dannenberg (2006) also claim that agentivity is part of that construction's defining semantics. 